\title{
Finansal Kuznets Eğrisi ve Ekonomik Küreselleşme İlişkisi Üzerine: OECD Ülkeleri İçin Gelir Eşitsizliği Temelli Bir Analiz
}

\author{
DOI: $10.26466 /$ opus.748836
}

*

\section{Onur Özdemir*}

* Dr. Öğr. Üyesi, İstanbul Gelişim Üniversitesi, İdari ve Sosyal Bilimler Fakültesi, İstanbul/Türkiye E-Posta: onozdemir@gelisim.edu.tr

ORCID: $\underline{0000-0002-3804-0062}$

\section{Öz}

Bu çalışma 1990-2017 dönemi için 27 OECD ülkesi temelinde finansal Kuznets hipotezinin geçerliliğini gelir eşitsizliği ve ekonomik küreselleşme olgularına bağh olarak araştırmaktadır. İlgili konunun incelenmesinin ardinda yatan temel motivasyon ana akm literatürün tersine belirli iktisadi, sosyal ve toplumsal değişkenlerin varlığında ulaşılacak bulguları farklı bir temele sahip olduğunu göstermektir. Diğer bir ifadeyle, finansal gelişme ile gelir eşitsizlĭgi arasında ters U-ilişkili finansal Kuznets hipotezinin geçerli olduğunu belirten geleneksel bakış açısının aksine elde edilen ampirik sonuçlar belirtilen hipotezin U-iliş̧ili bir yapıya sahip olduğunu göstermektedir. Panel sabit etkiler yöntemi ve iki aşamalı Sistem-GMM yaklaşımı çerçevesinde elde edilen modelleme sonuçlar ekonomik gelişme sürecinin ilk dönemlerinde finansal gelişme düzeyi artışının gelir eşitsizliğini azalttı̆̆ını ancak ileri dönemlerde alt ve üst gelir gruplarında yer alan hanehalklarının elde ettikleri gelir payı aralığının gelir eşitsizliğinin artışını tetikleyerek arttığııı belirtmektedir. Ayrıca ampirik bulgular ekonomik küreselleşmenin ana akım varsayımların aksine gelir eşitsizliğini artırdığın göstermektedir. Son olarak, mevcut çalışma gelir eşitsizliği üzerinde hem ekonomik küreselleşmenin hem de finansal gelişmenin bütünleşik etkisini araştırmak için yeni bir etkileşim değiş̧eni oluşturmaktadır. Belirtilen değişkene ait katsayılar finansal gelişmenin ekonomik küreselleşme ile sağlanmamasının ekonomik gelişmenin ileri dönemlerinde gelir eşitsizliğini artıracă̆ını göstermektedir. Bu nedenle hem ekonomik küreselleşme hem de finansal sektör gelişimi arasında gelirin bölüşümü açısından koşullu bir ilişkinin var olduğu görülmektedir.

Anahtar Kelimeler: Finansal Kuznets hipotezi, Gelir eşitsizliği, Ekonomik küreselleşme, Finansal sektör gelişmesi, Ekonomik gelişme. 


\title{
On the Relationship Between Financial Kuznets Hypothesis and Economic Globalization: An Income Inequality Based Analysis for OECD Countries
}

\begin{abstract}
This study examines the validity of the financial Kuznets hypothesis based on income inequality and economic globalization for 27 OECD countries over the 1990-2017 period. The main motivation for doing this study is to show that the findings to be obtained in the presence of certain economic, social, and common variables have a different basis, as opposed to the mainstream literature. In other words, in contrast to the traditional knowledge that the reverse U-related financial Kuznets hypothesis is valid between financial sector development and income inequality, the empirical results imply that the specified hypothesis has a $U$-related structure. In consideration of panel fixed-effects method and two-step system-GMM approach, the results of modeling structure indicate that the increase in the level of financial development reduces the income inequality in the early periods of the economic development process but the income share gaps of the households in the lower and upper-income groups increase in the later periods by stimulating an increase in income inequality. Moreover, the empirical findings show that unlike the mainstream assumptions about economic globalization, it increases income inequality. Finally, the study originates a new interaction variable to investigate the integrated effect of both economic globalization and financial development on income inequality. The coefficients of given variable indicate that the missing of providing financial development with economic globalization increases income inequality in the later periods of economic development. Therefore, it is observed that there a conditional relationship between economic globalization and financial sector development in terms of the income distribution.
\end{abstract}

Keywords: Financial Kuznets hypothesis, Income inequality, Economic globalization, Financial sector development, Economic development 


\section{Giriş}

Finansal sektördeki gelişme düzeyi ve gelir eşitsizliği arasındaki ilişki üzerine yapılan çok sayıda ampirik çalışma, farklı gelir düzeylerinde yer alan toplumsal grupların finans alanında yaşanan değişmelere paralel olarak doğrudan veya dolaylı açılardan gelir düzeylerinde zaman içerisinde sapmalar yaşadığını göstermektedir. Ancak mevcut literatürde finanseşitsizlik bağıntısını etkileyen değişkenler ve bu değişkenler ile bağlantılı sosyo-iktisadi ve politik belirleyenler üzerine bir fikir birliği bulunmamaktadır. Bu bağlama ek olarak, ilgili çalışmaların çok az bir kısmında finansal gelişme ve gelir eşitsizliği ilişkisi incelenirken küreselleşmenin boyutları analize dahil edilmiştir. Özellikle ekonomik küreselleşme çerçevesinde finansal gelişmenin bir diğer ayağını oluşturan finansal açıklık değişkeninin ilgili finans-eşitsizlik bağıntısında yer alması gerektiği düşünülmelidir. Bu açıdan mevcut çalışmayı literatürdeki çalışmalardan ayıran temel nokta ekonomik küreselleşme olgusunu ve buna bağlı ilgili değişkenleri analize dahil etmesidir. Ayrıca bir diğer önemli nokta da finansal Kuznets hipotezi ile gelir eşitsizliği arasındaki ilişkinin araştırılmasında, literatürde sınırlı bir finansal gelişmişlik değişkeninin kullanılması göz önünde bulundurularak finansal sektörün tüm alt bileşenlerini kapsayan değişkenler temelinde analizin yapılacak olmasıdır. Diğer bir ifadeyle, finansal sektör gelişmişliği finansın derinlik, erişim ve verimlilik açısından tüm alt bileşenlerini içeren üç farklı değişken tarafından ayrı olarak incelenecektir: (i) ağırlıklı ortalaması alınmış finansal sektör gelişmişlik endeksi, (ii) finansal kurumlar gelişmişlik endeksi ve (iii) finansal piyasalar gelişmişlik endeksi. Bu nedenle, finansal Kuznets hipotezinin geniş bir analitik çerçevede incelenmesinin finans sektörü gelişmesi temelinde literatürdeki kapsamının nadir olduğu ileri sürülebilir.

Ana akım literatürde finansal Kuznets hipotezi finansal sektör gelişimi ile gelir eşitsizliği arasındaki bağıntı çerçevesinde ters U-ilişkisine sahip bir korelasyon üzerine kurulu olarak yorumlanmaktadır. Örneğin, mevcut literatür içerisinde üç önemli çalışma finansal Kuznets hipotezi bağlamında zaman içerisinde gelişebilen finans-eşitsizlik ilişkisinin pozitif ve negatif yönlerini belirlemek için birbirlerini farklı açılardan tamamlamaktadır. Banerjee ve Newman (1993) ile Galor ve Zeira (1993)'ya göre, finans alanında daha yüksek bir gelişme düzeyi sağlamak, farklı sosyal sınıflar 
arasında önemli ölçüde düşük bir gelir eşitsizliğine yol açmaktadır. Bununla birlikte, Greenwood ve Jovanovic (1990) finans-eşitsizlik ilişkisinin zaman etkilerini araştırarak finansal sektör gelişiminin ilk dönemlerinde gelir eşitsizliğinin arttığını; ancak, ilerleyen dönemlerde ekonomik gelişme sürecinin hız kazanması ve sosyo-iktisadi değişimlere bağlı olarak gelir eşitsizliğinin azaldığını ve bu nedenle ters U-ilişkili hipotezin geçerli olduğunu belirtmektedir.

Finans-eşitsizlik bağıntısı üzerine yapılan öncü niteliğindeki araştırmalar literatürde farklı ampirik çalışmalar tarafından olumlanmış olup; aynı zamanda, finansal gelişme aşamasında birçok ülkenin farklılaşan iktisadi yapılarına ve küreselleşmenin boyutlarına dayanarak eleştiriye maruz kalmıştır. Bu nedenle, güncel çalışmalar temelinde elde edilen bulgular finansal sektör gelişimi ile gelir eşitsizliği arasındaki ters U-ilişkili finansal Kuznets hipotezinin çok farklı nedenlere bağlı olarak değişebileceğini ortaya koymaktadır. İlk olarak, Jaumotte vd. (2008) üretim sistemindeki teknolojik ilerlemenin ve küreselleşmiş ekonomik ilişkilerin toplam gelirin eşit dağılımı üzerindeki olumsuz etkilerine dikkat çekmiş ve finansal sektör gelişimi ile gelir eşitsizliği arasında pozitif bir ilişki bulunduğunu ortaya koymuşlardır. Ancak, yaptıkları analizlerin en önemli eksikliği finansal gelişmenin ölçülmesi için kullandıkları değişkenin sınırlı olması ve sadece piyasa derinliği göstergesi ile tahmin edilmesidir. Bu değişken temel olarak özel mevduat bankaları ve diğer finansal kurumlar tarafından sağlanan kredilerin Gayri Safi Yurtiçi Hasıla (GSYH)'ya oranı olarak ölçülmektedir. Bu nedenle, finansal erişim ve finansal verimlilik göstergelerinin gelir eşitsizliği üzerindeki etkilerini dikkate alan diğer değişkenler, verili ilişki için tek taraflı ampirik kanıtlar sağlayarak mevcut analizden önemli ölçüde dışlanmıştır. İkinci olarak Kappel (2010), Banerjee ve Newman (1993) ile Galor ve Zeira (1993)'nın finansal sektör gelişimi ile gelir eşitsizliği arasındaki ilişkinin ülkeler temelinde yapılan ampirik araştırmalara bağlı olarak doğrulandığını göstermiştir. Ayrıca Jaumotte vd. (2008)'nin tek taraflı ölçüm sorununu tekrarlayan Kappel (2010)'in finans-eşitsizlik bağıntısının içeriği sınırlı bir korelasyonun geçerliliğini ortaya koymaktadır. Üçüncü olarak Nikoloski (2012), finansal sektör gelişimi ve gelir eşitsizliği arasında ters U-ilişkili finansal Kuznets hipotezini doğrulayan ampirik kanitlar sunarak Greenwood ve Jovanovic (1990)'in bulgularının istatistiksel olarak anlamlı olduğunu belirtmiştir. Her ne 
kadar Nikoloski (2012)'nin çalışması ilgili hipotezin geçerliliğini doğrulayan istatistiksel kanıtlar ortaya koysa da finans sektörünün gelişimini özel sektöre sağlanan krediler (\% GSYH) üzerinden ölçerek finansal derinliği ele alan tek yönlü ve sınırlı bir analiz çerçevesinde ulaştığı sonuçlar nedeniyle teorik olarak genişletilmiş bir veri seti ile ayrıca doğrulanmayı gerektirmektedir. Bu bağlamda Nikoloski (2012)'nin finans-eşitsizlik bağıntısı üzerine yapmış olduğu varsayımlar takip edilerek finansal sektör gelişimini tahmin etmek için kullanılan ek değişkenlerin veya vekil değişkenlerin potansiyel çıtılara ters etkileri olabileceği ifade edilebilir. Son olarak, Tan ve Law (2012) ile Jauch ve Watzka (2016) ise belirtilen ampirik çıktıların tersi sonuçlar ortaya koyarak finansal Kuznets hipotezinin Uilişkili bir yapıya sahip olduğunu söylemektedirler. Tan ve Law (2012) ilgili U-ilişkili hipotezin varlığını gelişmekte olan ülkeler için ortaya koyarken Jauch ve Watzka (2016) bu olgunun düşük gelirli ülke grupları için sınamasını yaparak istatistiksel olarak anlamlı olduğunu belirtmiştir.

Tüm bu farklı bakış açıları çerçevesinde mevcut çalışmanın diğer çalışmalardan ayırt edici en önemli noktası finans sektörü gelişimi için geniş bir ölçüm yöntemine ve ülke örneklemine dayanıyor olmasıdır. Ayrıca bu çalışma küreselleşme göstergelerini başka bir etki kanalı olarak regresyon analizine dahil ederek ilgili literatürün bulgularını teorik ve varsayımsal temelde genişletmekte; finansal sektör gelişimi ile ekonomik küreselleşme göstergesi arasında etkileşim değişkeni ortaya çıararak gelir dağılımı üzerindeki etkilerini araştırmaktadır. Bunun yanı sıra, mevcut makale üretim sürecinde ortaya çıkan çelişkileri dikkate alarak gelir eşitsizliği ile finansal sektör gelişimi arasındaki ilişkiyi tahmin etmektedir. Bu nedenle, bireysel gelir dağılımı ölçeğinde yapılan analizin ileri çalışmalar için fonksiyonel gelir dağılımı varsayımları altında ele alınmasına olanak sağlayacak önsel bilgiler sunmaktadır.

Çalışmanın örneklemi ilgili ülkelerin gelir düzeylerinin büyük ölçüde farklı faktörlere bağlı olarak değişebildiği OECD ülkelerine dayanmaktadır. Bununla birlikte seçili ülkeler arasındaki bu farklılıklar, hanehalkları arasında çelişen çıkarların varlığında, finans-eşitsizlik bağının değişebileceğini iki faktör üzerinden etkileyebilmekte ve bu açıdan üzerinde düşünülmeyi gerektirmektedir. İlk olarak, kısa ve uzun dönem kıyaslamasına sahip analizlerde ekonomik, sosyal ve finansal faktörleri kapsayan çeşitli göstergeler kullanılarak toplam gelirin farklı ekonomik sistemlerde ve 
hanehalkı gruplarında yeniden dağıtımında yaşanan ayrışma dinamiği incelenmelidir. İkinci olarak finansal sektör temelinde, finansal piyasalar ve kurumlar için kalkınma sürecinin gelir dağglımı üzerinde zamana bağlı potansiyel etkilerinin birçoğu farklı ülkeler arasında ekonomik konumlarına göre sınıflandırma yoluyla araştırılmalıdır.

Finansal sektör gelişimi ve gelir eşitsizliği arasındaki ilişki üzerine mevcut olan yazın farklı ampirik sonuçlara ve teorik varsayımlara sahip olmasına rağmen, mevcut ilişkinin finansal Kuznets hipotezi bağlamında yapıldığı araştırmalar oldukça sınırlıdır. Özellikle finansal sektördeki gelişmeyi istatistiksel olarak tahmin etmek için çok dar bir veri setine bağlı olarak yapılan çalışmalar literatürde öne çıkmaktadır. Örneğin, özel kredi miktarının GSYH'ya oranı finansal sektör gelişimini açıklamak için vekil değişken olarak modellemelerde kullanılmaktadır. Bu anlamda, mevcut çalışmaların çoğu finans alanındaki kurumsal farklılıkların gelir eşitsizliği üzerindeki doğrudan ve dolaylı etkilerini açıklamakta eksik kalmaktadır. Başka bir ifadeyle, ilgili çalışmaların çoğu finans sektörünün kurumsal yapısındaki gelişim sürecini dışlayarak piyasa kısmındaki gelişim göstergelerini kullanmaları nedeniyle belirli olguların ortaya çıkmasına neden olmaktadır. İlk olarak, beşeri sermaye finansal kredilere yönelik potansiyel ihtiyaçlar doğrultusunda daha yüksek bir finansal gelişme düzeyi elde etmek için önemli değişkenlerden biri olarak ele alınmalıdır. İkincisi, finans sektöründeki koşulları farklılaştırarak hanehalklarına yeni fırsatlar sağlanması koşuluyla reel yatırım seviyesi artırılabilir. Rajan (2010)'a göre bu konu üzerindeki çalışmalar temelinde, finansal gelişme-gelir eşitsizliği ilişkisinde meydana gelen değişimleri açıklamak için öncelikli olarak yeniden dağıtım vergisinin politik bağlamı üzerinde durmak gerekmektedir. $\mathrm{Bu}$ anlamda çalışmasının bulguları politik faktörlerin finans sektörünün gelişimi ile yüksek dereceli bir korelasyona sahip olduğunu ve dolayısıyla gelir eşitsizliğini artırıcı bir etki ortaya çıkardığını belirtmektedir. İlgili sonuçlar yeniden dağıtımın vergilendirmesine yönelik geleneksel örneksemelerin politik alandaki eksiklikler nedeniyle farklı sosyal kesimlere etkisinin sınırlı olduğunu göstermektedir. Örneğin, Amerika'daki hanehalklarına özgü ortaya konulan araştırmanın sonuçları politika yapıcılarının düşük gelirli grupların finansal kredilere erişmesi için yeni yollar ortaya çıarabileceğini belirtmektedir. Rajan (2010)'ın çalışmasına ek olarak, Bumann ve Lensink (2016) ile Haan ve Sturm (2017) finansal 
serbestleşmenin giderek artan ekonomik küreselleşme düzeyine paralel olarak gelir eşitsizliği üzerindeki etkisinin finansal gelişme düzeyine bağlı olduğunu belirtmektedir. İlgili ampirik çıktılar, alternatif açıklama mekanizmalarının ve kullanılan vekil değişkenlerin finansal gelişme ile gelir eşitsizliği arasındaki ilişkiyi analiz etmek için mevcut araştırmaya eklenmesi gerektiğini göstermektedir.

Finansal gelişme-gelir eşitsizliği bağıntısı çerçevesinde yapılan üç temel çalışma kapsamında finansal Kuznets hipotezine dayalı olarak daha ileri teknik analizler yapabilmek için değişkenlerin teorik benzerlikleri kadar farklılıkları da ortaya konulmalıdır. Örneğin, Galor ve Zeira (1993) gelir eşitsizliği üzerinde finansal kredilerin önemine vurgu yaparak beşeri sermaye yatırımlarının da ele alınması gerektiğini belirttikleri bir analitik yapıya vurgu yapmaktadır. Banerjee ve Newman (1993) ise hanehalklar1nın mesleki tercih bağımlılığı ve kredi kullanılabilirliği arasındaki çift yönlü korelasyonu araştırmaktadır. Ancak Greenwood ve Jovanovic (1990) finansal aracllık sürecini hanehalkının artan sermaye geliri düzeyinin ve dolayısıyla portföy seçimlerinin durumunun ele alınması ile açılarlar. İlk olarak, yoksul hanehalkı kesiminin ekonomik kalkınmanın erken aşamalarında sosyal ve ekonomik ihtiyaçları için gerekli olan finansal kaynaklara ulaşamadığı varsayılmaktadır. Hanehalklarının düşük gelire sahip kesimi için belirtilen finansal kaynaklara ulaşmada yaşadıkları sıkıntıların ardındaki nedenler ise öncelikli olarak iki faktöre bağlı bulunmaktadır: (i) finansal sektörün gelişme düzeyindeki eksiklik ve (ii) ekonomik büyüme oranlarının istihdam yaratıcı etkisinin sınırlı kalması. Bu açıdan değerlendirildiğinde farklı alanlarda kullanılan bankacılık kaynakları hanehalklarının üst gelir grubunda yer alan kesimi tarafından kolaylıkla elde edilebilmektedir. Böylece ekonomik kalkınmanın erken dönemlerinde finansal gelişme düzeyindeki artış daha yüksek bir gelir eşitsizliğine yol açmaktadır. Ancak ekonomik koşullara erişimdeki olanakların artışı paralelinde yoksul kesimde yer alan hanehalkları finansal kaynakları kullanarak çeşitli sosyo-ekonomik dinamiklere bağlı olarak çok daha varlıklı bir pozisyona sahip olmaya yönelik toplumsal bir değişim gösterebilirler. Mevcut bağlamda, toplam nüfusun küçük bir yüzdesinin elinde yoğunlaşarak gelir eşitsizliği artışını beraberinde getiren koşullar zamanla yoksul kesim lehine düzelerek artan ekonomik gelişme paralelinde gelir eşitsizliği düzeyinde azalmaya neden olur. 
Bu çalışmanın temel motivasyonu verili teorik kısıtlamaların önüne geçilmesi ve analitik düzlemin genişletilmesi çerçevesinde finansal piyasaların ve kurumların ayrı ayrı ele alınarak incelendiği bir yapının makro iktisadi, yapısal ve üretim sürecinde rol alan faktörler arasında değişen pazarlık gücü değişkenleri paralelinde yapılan analiz sonucunda elde edilecek finansal gelişme-gelir eşitsizliği ilişkisinin mevcut literatürün tersi bulgular ürettiği üzerine kurulu olmasıdır. Diğer bir ifadeyle, ilgili yazındaki teorik ve analitik eksikliklerden yola çıkarak, geniş bir finansal gelişme veri tabanına bağlı olarak elde edilen analiz sonuçlarının daha kapsamlı ve ters U-ilişkili finansal Kuznets hipotezini reddeden bulgular ortaya çıkaracağı varsayılmaktadır. Bu nedenle, mevcut çalışma literatürde finansal gelişmenin gelir eşitsizliği üzerindeki etkisini ölçmek için kullanılan değişkenler grubunun daha geniş bir etki alanında test edilebilmesini beraberinde getirecektir. Sonuç olarak, çalışmada ulaşılacak ampirik çıktılar finansal gelişme ile gelir eşitsizliği arasında ters U-ilişkili finansal Kuznets hipotezini doğrulayan ana akım yazının finansal gelişme açısından daha geniş bir değişken grubu ile ölçümü çerçevesinde aksi kanitlar sunabileceğini göstermektedir. Böylece hanehalklarının heterojen özellikleri paralelinde üretim sürecindeki konumlarının da analize eklenmesi ile finansal Kuznets hipotezinin U-ilişkili bir çerçeveye sahip olduğu sonucuna ulaşılabilir. Bu bağlamı takiben ampirik sınamaların yapıldığı bölümde test edilecek finansal gelişme-gelir eşitsizliği ilişkisine ait hipotezler şu şekilde belirtilebilir:

\section{Hipotez 1}

Gelir eşitsizliği ile finansal gelişme arasında uzun dönemli pozitif bir ilişki bulunmaktadır.

\section{Hipotez 2}

Finansal gelişim ile ekonomik küreselleşme temelinde oluşturulan etkileşim değişkeni, ekonomik kalkınmanın erken dönemlerinde gelir eşitsizliği ile negatif, ancak ileri dönemlerde pozitif ilişkiye sahiptir.

\section{Hipotez 3}

Ekonomik küreselleşme ile gelir eşitsizliği arasında uzun dönemli pozitif bir ilişki bulunmaktadır. 


\section{Hipotez 4}

Gelir eşitsizliği ile finansal sektör gelişmesi arasında finansal Kuznets hipotezi bağlamında ana akım literatürün sunduğu bulguların aksine U-ilişkili bir korelasyon vardır.

Belirtilen hipotezler çerçevesinde OECD'ye üye seçili ülke örnekleminde 1990-2017 dönemini kapsayan ampirik çalışma finansal gelişme ve gelir eşitsizliği arasındaki ilişkiyi panel veri analizi bağlamında sabit etkiler metodu ve iki aşamalı Sistem Genelleştirilmiş Momentler yöntemi (Sistem-GMM) ile analiz etmektedir. Bu anlamda mevcut ampirik yaklaşım ülke-içi gelir eşitsizliğinin finansal Kuznets hipotezi açısından analizine dayanmaktadır. Panel sabit etkiler yönteminin kullanılmasının ardındaki temel mantık ülkeye özgü etkileri regresyon tahmininde dişlayarak kontrol değişkenleri ile hata terimi arasındaki ilişkiyi düzeltmektir. Ayrıca, panel veriye ait sabit etkiler yöntemi içsellik sorununu düzeltmediğinden, mevcut çalışmada ters nedensellik ve dışlanmış değişken yanlılık sorunlarını da ele alan Sistem-GMM yaklaşımından yararlanılmaktadır.

Makalenin bundan sonraki kısmındaki içerik şu şekilde özetlenebilir: Bir sonraki bölümde model ve verilerin ayrıntıları verilecektir. Devaminda hem panel veri analizine dayalı sabit etkiler yöntemi hem de Sistem-GMM yaklaşımı çerçevesinde elde edilen ampirik sonuçlar açıklanacaktır. Son kısımda ise sonuçlar özetlenmektedir.

\section{Yöntem ve Bulgular}

Finansal sektör gelişmesinin gelir eşitsizliği üzerindeki zamana dayalı etkilerini tahmin etmek için öncelikli olarak kullanılması gereken temel teorik yaklaşım ilgili değişken için verilerin seçim prosedürüne dayanmaktadır. Bu açıdan, finansal gelişme-gelir eşitsizliği ilişkisini tahmin etmek için mevcut makalede IMF veri tabanından elde edilen finans değişkenleri kullanılmaktadır. Finansal sektör gelişmesi için IMF veri tabanından yararlanmanın başlıca nedeni finans piyasalarının ve kurumlarının derinlik, erişim ve verimlilik alt değişkenlerinin bir bütün halinde ilgili değişkenler içine dahil edilmiş olması ve böylece gelir eşitsizliği üzerindeki çok yönlü etkilerinin analiz edilebilmesidir. Bu nedenle, çok sayıda çalışmanın toplam kredi oranı (\% GSYH) değişkenini finans sektörü gelişiminin gelir 
eşitsizliği üzerindeki etkisini ölçmek için kullandığı ve bu durumun çok ciddi analitik sınırları olduğu göz önüne alındığında, IMF veri tabanından elde edilen kapsamlı finans sektörü gelişme değişkeni finansal Kuznets hipotezinin geçerliliğini sınamak için ana akım literatürden farklı bir yapı ortaya çıkarmaktadır. Ayrıca finansal sektör gelişimi için elde edilen verilerin farklılaşan özellikleri ilgili örneklem grubundaki ülkeleri finansal yapılarını göz önünde tutarak sınıflandırabilmemizi sağlamaktadır. Örneğin, Svirydzenka (2016) finansal piyasaların ve finansal kurumların ayrı bir biçimde ele alınmasının finansal hizmetlerin sağlanmasını kolaylaştırdığını belirtmektedir. Bu nedenle, derinlik gibi finansal gelişimin bir alanına daha fazla vurgu yapılması ve finansal ilişkiler etkinliği ve erişiminin analizden dışlanması finansal sektör gelişimi ile gelir eşitsizliği arasındaki ilişkinin kısmi bir şekilde yorumlanmasını beraberinde getirmektedir. OECD'ye üye ülkeler gelişmiş ve gelişmekte olan ekonomiler olarak sınıflandırıldığından, finansal sistemleri büyük ölçüde verimlilik ve erişim endekslerinin finansal sektör gelişimi için derinlik endeksi gibi analizde kullanılmasını gerektirmektedir. Başka bir deyişle, Čihák vd. (2012) ve Aizenman vd. (2015)'nin belirttiği gibi ülkeler arasındaki farklılaşan finansal yapılar nedeniyle finansal gelişme-gelir eşitsizliği ilişkisi üzerine yapılan araştırmaların daha kapsamlı sonuçlar ortaya çıkarabilmeleri için finansal gelişmişlik göstergelerinin kullanıldığı regresyon tahminlerinde farklı alt değişkenlere de yer vermeleri gerekmektedir.

Bu konu dikkate alındığında, mevcut çalışma finansal piyasalar ve kurumlar için derinlik, erişim ve verimlilik alt değişkenlerinden oluşan finansal sektör gelişme verilerini kullanmaktadır. Ortalama olarak, veriler 0 (tamamen az gelişmiş) ile 100 (tamamen gelişmiş) arasında değişen endeks değerlerine sahip bulunmaktadır. Bu bağlamda ampirik analiz hem finansal piyasalar hem de finansal kurumlar dahil olmak üzere ağırlıklı ortalaması alınmış finansal sektör gelişme değişkeninin ve alt bileşenlerinin gelir eşitsizliği üzerindeki etkisini ayrı ayrı ele alarak incelemektedir. Finansal Kuznets hipotezi ile ilgili olarak bahsedilen değişkenlerin gelir eşitsizliği ile korelasyonunun analiz edilmesini ele alan literatür ise oldukça sınırlıdır. Böylece mevcut makalede vekil değişkenlerin ve kontrol değişkenlerinin kullanılması çerçevesinde ilgili literatürün analitik sınırlamalarından kurtulmuş olunması planlanmaktadır. 
Finansal sektör gelişme endeksinin yanı sıra, mevcut çalışma aynı zamanda Gygli vd. (2019) tarafından oluşturulan ve hem finansal hesap ve ticaret rejimi açıklığını hem de Doğrudan Yabancı Yatırım (DYY) akışlarını içeren ekonomik küreselleşme endeksini analize dahil etmektedir. KOF küreselleşme veri tabanından elde edilen ekonomik küreselleşme endeksi, finans alanında ve ticarette liberalleşme politikalarının farklı boyutlarını ölçmektedir. Bununla birlikte, ilgili çalışma sadece ekonomik küreselleşme endeksine odaklanmayıp, alternatif olarak alt bileşenlerinin de analize dahil edilmesi ile genişletilmiş bir altyapının gelir eşitsizliğindeki rolünü ölçme imkanı ortaya çıkarmaktadır. İlk olarak, ticaret rejimi açılığının gelir eşitsizliği üzerindeki etkisini ölçmek için ihracat ve ithalat toplamının GSYH'ya oranı ölçülerek elde edilen değerler GSYH fiyatından arındırılmıştır. İkinci olarak, finansal açıklığın gelir eşitsizliği üzerindeki etkisini hesaplamak için Chinn ve Ito (2006) tarafından geliştirilen ve IMF'nin AREAER (Annual Report on Exchange Arrangements and Exchange Restrictions) raporlarında sınır ötesi finansal işlemlerde kısıtlamalar listesini kodlayan ve ikili kukla değişken ölçümüne dayanan finansal açıklık değişkeni kullanılmaktadır. Ekonomik değişkenler üzerindeki sınırlamalar yerli ve yabancı sermaye için önemli ölçüde düşük olsa da bu değişkenin fiili özelliği sınır ötesi işlemlere yol açmamaktadır.

Gelir eşitsizliğini ölçmek için kullanılan değişken ise Solt (2020) tarafından oluşturulan Standardize Edilmiş Dünya Gelir Eşitsizliği Veri Tabanından (SWIID) elde edilen Gini katsayıdır. SWIID üzerinden hesaplanan Gini katsayısının teorik ve analitik açıdan birçok avantajı bulunmasına rağmen mevcut çalışma için üzerinde durulması gereken avantaj ise birçok çalışmanın Gini katsayına ulaşmada karşılaştıkları sorunları çözmesi ve böylece dengeli panel veri elde edilmesini bizlere sağlamasıdır. Özellikle gelişmiş ve gelişmekte olan ülke ekonomileri için dahi elde dilmesi sıkıntılı olan Gini katsayısı Solt (2020) tarafından oluşturulan SWIID içerisinde zaman boyutu olarak geniş bir altyapıya sahip bulunmaktadır. Hesaplanan Gini katsayısı gelir eşitsizliğini vergi ve transferlerden arındırılmamış (pre-tax, pre-transfer) ve arındırılmış (post-tax, post-transfer) olarak iki ayrı gösterge altında sınıflandırılmaktadır. Analiz kısmında ise vergi ve transferlerden arındırılmış ve "Gini_Net" olarak adlandırılan katsayı kullanılmaktadır. Solt (2020)'a göre SWIID ulaşılabilecek en çok sayıda ülke ekonomisine ve zaman serisine bağlı olarak mevcut gelir 
eşitsizliği verilerinin birbirleriyle karşılaştırılmasını büyük oranda sağlamaktadır. Ancak ülkelerin gelir eşitsizliği seviyelerinin birbirleri ile karşılaştırılması mümkün olsa da ilgili konu üzerinde politika üretme aşamasindaki sorunlar devam etmektedir. SWIID tahminlerinin standart hatalarında ortaya çıkan bu karşılaştırma sorunları araştırmacıların ülkeler arası gelir eşitsizliği farklılıklarını kıyaslamada belli belirsizler üzerine odaklanmasını gerektirmektedir (Solt, 2016, s.14).

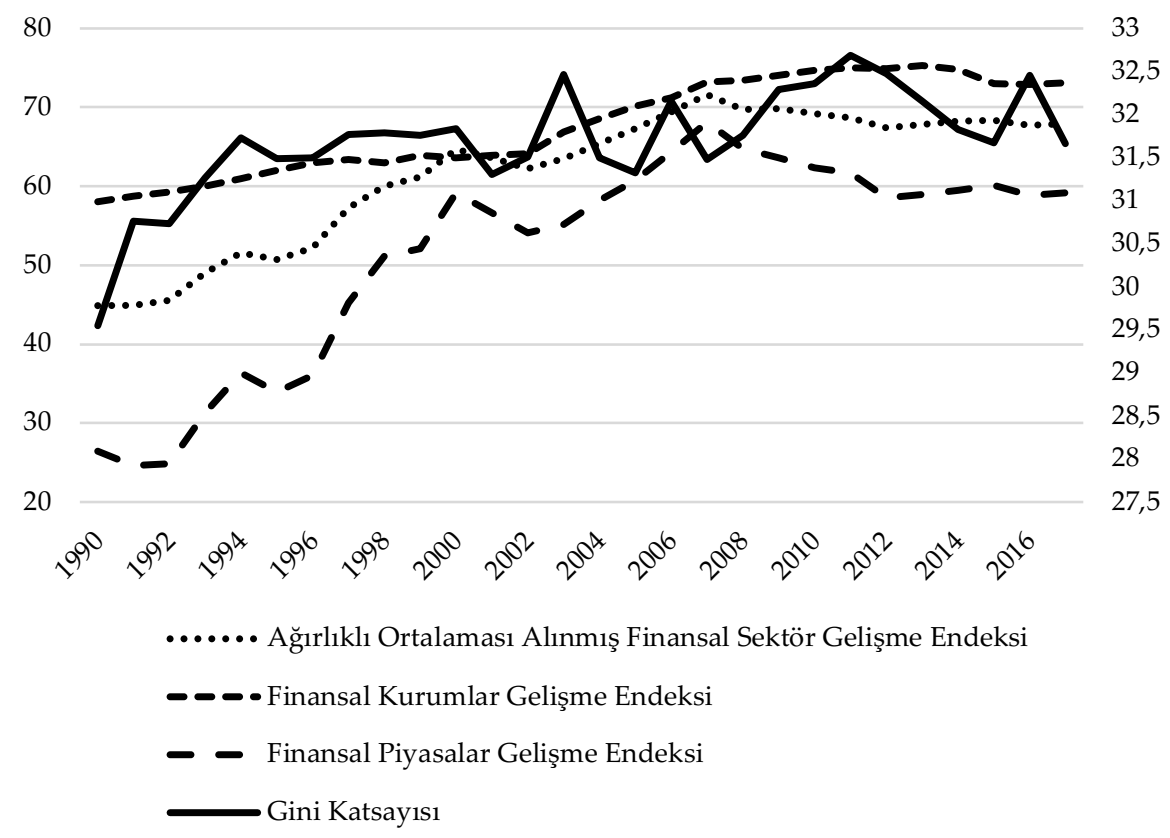

Şekil 1. Gelir Eşitsizliği ve Finansal Sektör Gelişimi Eğilimi (Kaynak: Solt, 2020; IMF Data)

Analiz kısmında kullanılacak bu temel değişkenler çerçevesinde Şekil 1 OECD içerisinden seçilen ülke örneklemleri arasında hem finansal sektör gelişimi endekslerini hem de gelir eşitsizliğinin zaman içerisindeki eğiliminde yaşanan değişimleri 1990-2017 arası dönem için göstermektedir. Mevcut dönemin 1990 yılından başlamasının temel nedeni seçili OECD ülkelerinin birçoğunun bu tarih itibarıyla yoğun bir biçimde hem finans hem de ticaret açısından liberalleşme politikalarını benimsemesidir. Şekil 
1'de sol taraf finansal sektör gelişimi değişkenlerinin düzeylerini gösterirken, sağ taraf Gini katsayısının zaman içerisindeki değişimini göstermesi açısından gelir eşitsizliği düzeyini betimlemektedir.

Bir yandan 1990-2017 arası dönem için panel veri analizi dahilinde mevcut çalışma, finansal sektör gelişmesi ve gelir eşitsizliği arasındaki ilişkiyi Driscoll ve Kraay (1998) tarafından geliştirilen sabit etkiler yöntemini kullanarak dirençli standart hata tahmincileri ile tahmin etmekte; diğer yandan, Sistem-GMM tahmincisi dinamik değişimleri test etmek ve içsellik sorununu kontrol etmek için ayrıca kullanılmaktadır. Özellikle Driscoll ve Kraay (1998)'ın yönteminin kullanılması modellerde değişen varyans, otokorelasyon ve yatay kesit bağımlılı̆̆ sorunlarının var olmasına bağlı bulunmaktadır. Bu bağlamda, çalışma için belirtilen hipotezler panel sabit etkiler modeli için Denklem (1) ile tahmin edilmektedir:

$$
\begin{gathered}
G I N I_{i t}=\alpha_{i}+\beta_{1} F D_{i t}+\beta_{2} F D_{i t}^{2}+\beta_{3} E C_{i t}+\beta_{4} E C_{i t}^{2}+\beta_{5} F D * E C_{i t} \\
+\beta_{6}(F D * E C)_{i t}^{2}+\beta_{j} X_{i t}+\theta_{t}+\mu_{i}+\varepsilon_{i t}
\end{gathered}
$$

ve ayrıca modellere ait dinamik değişimler ve potansiyel içsellik sorunu Sistem-GMM yaklaşımı temelinde Denklem (2) ile test edilmektedir:

$$
\begin{aligned}
\Delta G I N I_{i t}=\beta_{k} \Delta & G I N I_{i t-k}+\beta_{1} \Delta F D_{i t-k}+\beta_{2} \Delta F D_{i t}^{2}+\beta_{3} \Delta E C_{i t} \\
& +\beta_{4} \Delta E C_{i t}^{2}+\beta_{5} \Delta F D * E C_{i t}+\beta_{6} \Delta(F D * E C)_{i t}^{2} \\
& +\beta_{j} \Delta X_{i t-k}^{\prime}+\Delta \theta_{t}+\Delta \varepsilon_{i t}
\end{aligned}
$$

İlgili denklemlerde GINI gelir eşitsizliğini ölçmek için kullanılan Gini_Net katsayını, FD tüm finansal sektör gelişme değişkenlerini, FD² ise FD değiş̧kenlerinin karesini, EC ekonomik küreselleşme endeksini, $\mathrm{EC}^{2}$ ise EC değişkeninin karesini, FD*EC finansal sektör gelişimi ile ekonomik küreselleşme değişkeni arasında kurulan etkileşim terimini, $\left(\mathrm{FD}^{*} \mathrm{EC}\right)^{2}$ ise $\mathrm{FD}^{*} \mathrm{EC}$ değişkeninin karesini, $\mathrm{X}$ ise işgücüne katılma oranı, işsizlik oranı, kişi başına GSYH, finansal açıklık, reel ticaret açıklığı, refah temelli toplam faktör verimliliği endeksi, beşeri sermaye endeksi ve devlet harcama payı (\% GSYH) gibi kontrol ve vekil değişkenlerinin bir vektörüdür. Finansal sektör gelişmesinin gelir eşitsizliği üzerindeki etkisini betimleyen hipotez $1^{\prime}$ i takiben $\beta_{1}$ katsayısı negatif, $\beta_{2}$ katsayısı ise pozitif ve istatistiksel olarak anlamlı olmalıdır. U-yönlü ilişkinin geçerli olduğu varsayıldığı finansal 
Kuznets hipotezine göre makroekonomik ve yapısal değişkenler de dahil olmak üzere kontrol değişkenlerinin verili korelasyon düzenine potansiyel etkileri olmalıdır. Diğer bir ifadeyle, mevcut makale finansal gelişmegelir eşitsizliği bağıntısının sosyo-ekonomik yapısındaki değişimleri beraberinde getiren durumları ortaya çıkarak U-ilişkili finansal Kuznets hipotezinin ana akım bakış açısından farklı olarak ilgili kontrol ve vekil değişkenlerinin varlığında geçerli olduğunu göstermektedir. Örneğin, hipotez 2 'yi takiben, ampirik altyap temelinde $\beta_{3}$ ve $\beta_{4}$ katsayılarının sırasıyla negatif ve pozitif olması gerekmektedir. Ayrıca FD*EC ve (FD*EC)2 değişkenlerinin katsayılarının, yani $\beta_{5}$ ve $\beta_{6}$, sirasıyla negatif ve pozitif olması beklenmektedir. Tüm bu önsel istatistiksel varsayımlar, finansal Kuznets hipotezinin ana akım literatürdeki bulgularıyla çelişmektedir. Ek kısmında, Tablo A1 veriler ile ilgili kaynakların detaylarını göstermekte, Tablo A2 ise açılayıcı istatistikleri sunmaktadır. Bundan sonraki bölümde ilgili hipotezler kontrol ve vekil değişkenleri temelinde sınanmakta ve böylece finansal Kuznets hipotezinin geçerliliği test edilmektedir.

\section{Temel Analiz Sonuçları}

Bu bölüm analitik ve teorik altyapı dahilinde ortaya çıabilecek ampirik sorunları düzeltmek adına yararlanılacak olan yöntemler çerçevesinde iki ayrı alt bölümü ayrılmıştır. İlk olarak, ilgili alt bölüm model parametrelerinin sabit varsayıldığ 1 ve dirençli standart hata tahminlerini içeren panel veri temelli sabit etkiler yöntemine bağlı olarak elde edilen ampirik sonuçları özetlemektedir. İkinci olarak, diğer alt bölümde ise mevcut çalışma dinamik ölçekli değişimleri dikkate alarak ve içsellik sorununa odaklanarak ilgili modellerin Sistem-GMM yaklaşımı ile test edilmesine ayrılmıştır. Bu bağlamda her tahmin yöntemi dirençli standart hata tahminleri çerçevesinde istatistiksel olarak güçlü katsayı değerleri elde etmek adına birbirini teorik açlardan tamamlamaktadır.

\section{Panel Sabit Etkiler Yöntemi Analiz Sonuçları}

Panel sabit etkiler yöntemi için elde edilen ampirik sonuçlar ağırlıklı ortalamaya sahip finansal gelişme endeksi (Fin_Dev), finansal kurumlar endeksi (Fin_Inst) ve finansal piyasalar endeksinin (Fin_Mar) sirasıyla kullanıldığ1 modeller için Tablo 1, Tablo 2 ve Tablo 3'te belirtilmektedir. Ele 
alınan her modelleme içerisinde mevcut çalışma alternatif olarak finansal gelişme değişkenlerinin gelir eşitsizliğini etkilemede istatistiksel anlaml1lığa sahip olup olmadığı ayrı ayrı ele alınmakta ve böylece kapsamlı bir teorik içeriğin oluşturulmasına olanak sağlamaktadır. Çalışmanın bağlı olduğu teorik varsayım çerçevesinde panel sabit etkiler yönteminin kullanılmasındaki temel amaç iç (within) tahmin edicinin üretilmesidir. Finansal sektör gelişimi endekslerinin gelir eşitsizliği üzerinde hem finansal kurumlar hem de finansal piyasalar açısından farklı etkileri olabileceğinde, ilgili alt değişkenler arasındaki ayrım çalışmanın içeriğine ait olarak finansal bileşenlerin toplam gelirin bölüşümünde güçlü bir etkisi olan analitik ve teorik bilgiler sağlayabilir. Ayrıca finansal sektör gelişimi için ek alt değişkenlerin analize dahil edilmesi, bu çalışmanın diğer ana akım çalışmalardan ayırt edici noktalarının ortaya çıkarılmasına ve bunların istatistiksel olarak kontrol edilmesine neden olmaktadir.

Finansal sektör gelişimi endekslerinin gelir eşitsizliği üzerindeki etkilerini ayrı ayrı kontrol etmeye yönelik olarak, mevcut çalışma öncelikle Tablo 1'de hem finansal kurumlar hem de finansal piyasalara özgü gelişim endekslerinin ağırlıklı ortalamasını içeren değişken temelinde analize başlamaktadır. Tablo 1 içerisinde kurgulanan modellemeler sırasıyla finansal kurumlar ve finansal piyasalara özgü gelişme endekslerinin gelir eşitsizliği üzerindeki etkilerinin ele alındığı Tablo 2 ve Tablo 3 'te de test edilmektedir. İlgili sonuçlar önsel olarak şu şekilde belirtilebilir. Ağırlıklı ortalamaya sahip finans sektörü gelişim endeksi ve finansal piyasalar gelişim endeksinin yer aldığı Tablo 1 ve Tablo 3'teki sonuçlar U-ilişki finansal Kuznets hipotezinin istatistiksel olarak anlamlı olduğunu belirtmektedir. Diğer bir ifadeyle, ekonomik gelişme sürecinin toplumsal tabana yayılmaya başladığ 1 ilk dönemlerde finansal kaynaklardaki artışa paralel olarak toplumun büyük bölümünün bu kaynaklardan yararlanmaya başladığı ve böylece büyük oranda her kesimin gelirlerini belli ölçüde artırdığı varsayılmaktadır. Ancak ilerleyen süreçte mevcut kaynaklar ekonomik gelişme sürecine paralel olarak daha yüksek oranda üst gelir gruplarına yönlendirilerek hanehalkları arasındaki gelir paylarındaki farkın artışı ile sonuçlanmaktadır. Burada özellikle Tablo 1'de her iki alt değişkenin ağırlıklı ortalamasının ele alındığı finansal gelişim değişkeni finansal Kuznets hipotezinin yorumlanması için temel gösterge olsa da alt değişkenlerin sonuçları da büyük oranda kapsayıcı bilgiler sunmaktadır. 
Ancak Tablo 2' de elde edilen sonuçlar ise ana akım literatürü destekleyen bulgularla eş bir yapıya sahiptir. Diğer bir deyişle, finansal kurumlara ait gelişim endeksi ters U-ilişkili finansal Kuznets hipotezinin geçerli olduğunu söylemektedir. Bu açıdan hangi nedenlerden dolayı diğer sonuçlarla çeliştiği üzerinde durulmayı gerektirmektedir. Her ne kadar Tablo 2'deki sonuçlar diğer elde edilen sonuçlarla çelişse de ortalama olarak U-ilişki finansal Kuznets hipotezinin varlığı Tablo 1'de kapsamlı finansal sektör gelişme değişkeni çerçevesinde elde edilen sonuçlara bağlı olarak belirtilen şu faktörler temelinde doğrulanmaktadır: (i) ekonomik gelişme düzeyi, (ii) ekonomik küreselleşme düzeylerinde farklılıklar, (iii) devletin ekonomi içerisindeki payı ve (iv) hanehalklarının üretim sürecindeki konumları.

Yukarıda belirtilen faktörlerle bağlantılı olarak, Tablo 1'deki Model 1 ve Model 2, finansal sektör gelişme endeksinin kontrol değişkenlerinin regresyon analizine dahil edilmediği durumda gelir eşitsizliği ile arasındaki kısmı tahmin sonuçlarını göstermektedir. Elde edilen sonuçlar finansal gelişme ile gelir eşitsizliği arasında yüksek bir korelasyon olduğunu göstermektedir. Model 1'e göre finansal gelişmedeki artış gelir eşitsizliğini artırmaktadır. Model 2' de ise bu olgunun ekonomik gelişme sürecinin ileri dönemlerinde de geçerli olduğu görülmektedir. Not etmek gerekir ki, kısmi analiz sonuçlarında U-ilişkili finansal Kuznets hipotezi istatistiksel olarak doğrulanmamaktadır. Bunun en önemli nedeni ise kontrol değişkenlerinin ve diğer belirleyicilerin analizden dışlanmış olmasıdır. Bu amaçla diğer modellemeler ilgili ilişkinin diğer değişkenlerin etkisinde geçerliliğini test etmektedir. Örneğin, Model 3 regresyon analizine ekonomik küreselleşme endeksini (Econ_Glob) kapsayan değişkeni dahil etmektedir. Elde edilen sonuçlar, finansal ve ticari açılık ile DYY akışları çerçevesinde oluşturulan ekonomik küreselleşme endeksi ile gelir eşitsizliği arasında pozitif bir korelasyonun var olduğunu göstermektedir. 
Finansal Kuznets Eğrisi ve Ekonomik Küreselleşme İlişkisi Üzerine: OECD Ülkeleri İçin Gelir Eşitsizliği Temelli Bir Analiz

Tablo 1. Sabit Etkiler Yöntemine Bağh Regresyon Sonuçları (Ă̆ırlıklı Ortalaması Alınmış Finansal Sektör Gelişme Endeksi Temelinde)

\begin{tabular}{|c|c|c|c|c|c|c|c|c|c|c|}
\hline, & $(1)$ & $(2)$ & (3) & (4) & (5) & (6) & (7) & (8) & (9) & (10) \\
\hline \multirow[t]{3}{*}{ Fin_Dev } & $0.037^{* *}$ & -0.057 & - & - & - & - & - & - & & - \\
\hline & * & & $\begin{array}{c}0.135^{* *} \\
*\end{array}$ & $\begin{array}{c}0.136^{* *} \\
*\end{array}$ & $\begin{array}{c}0.122^{* *} \\
*\end{array}$ & $\begin{array}{c}0.139^{* *} \\
*\end{array}$ & $\begin{array}{c}0.141^{* *} \\
*\end{array}$ & $\begin{array}{c}0.154^{* *} \\
*\end{array}$ & & $\begin{array}{c}0.135^{* *} \\
*\end{array}$ \\
\hline & $(0.010)$ & $(0.049)$ & $(0.039)$ & $(0.038)$ & $(0.034)$ & $(0.038)$ & $(0.034)$ & $(0.032)$ & & $(0.033)$ \\
\hline \multirow[t]{2}{*}{ Fin_Dev ${ }^{\wedge} 2$} & & $0.080^{* *}$ & $\begin{array}{c}0.116^{* *} \\
*\end{array}$ & $\begin{array}{c}0.114^{* * *} \\
*\end{array}$ & $\begin{array}{c}0.108^{* *} \\
*\end{array}$ & $\begin{array}{c}0.114^{* * *} \\
*\end{array}$ & $\begin{array}{c}0.117^{* *} \\
*\end{array}$ & $\begin{array}{c}0.127^{* * *} \\
*\end{array}$ & & $\begin{array}{c}0.121^{* *} \\
*\end{array}$ \\
\hline & & $(0.037)$ & $(0.031)$ & $(0.031)$ & $(0.028)$ & $(0.030)$ & $(0.026)$ & $(0.026)$ & & $(0.027)$ \\
\hline \multirow[t]{2}{*}{ Econ_Glob } & & & $\begin{array}{c}0.065^{* *} \\
*\end{array}$ & $\begin{array}{l}0.067^{* *} \\
*\end{array}$ & $\begin{array}{c}0.078^{* *} \\
*\end{array}$ & $\begin{array}{c}0.078^{* *} \\
*\end{array}$ & $\begin{array}{c}0.069^{* *} \\
*\end{array}$ & $\begin{array}{c}0.063^{* *} \\
*\end{array}$ & & \\
\hline & & & $(0.005)$ & $(0.006)$ & $(0.008)$ & $(0.007)$ & $(0.006)$ & $(0.006)$ & & \\
\hline \multirow[t]{2}{*}{ TFP } & & & & 1.581 & $2.593^{*}$ & $\begin{array}{c}4.310^{* *} \\
*\end{array}$ & $3.833^{* *}$ & $3.892^{* * *}$ & 1.490 & $3.083^{*}$ \\
\hline & & & & $(1.126)$ & $(1.391)$ & $(1.454)$ & $(1.504)$ & $(1.469)$ & $(1.087)$ & $(1.634)$ \\
\hline \multirow[t]{2}{*}{ Log(GDPperCap) } & & & & & $-2.653^{*}$ & - & - & - & -1.663 & -2.141 \\
\hline & & & & & $(1.396)$ & $\begin{array}{l}6.556^{* *} \\
(2.648)\end{array}$ & $\begin{array}{l}4.805^{* *} \\
(2.044)\end{array}$ & $\begin{array}{l}4.426^{* *} \\
(2.019)\end{array}$ & $(1.384)$ & $(2.867)$ \\
\hline \multirow[t]{2}{*}{ Human_Cap } & & & & & & $2.379^{* * *}$ & $\begin{array}{c}2.137^{* *} \\
*\end{array}$ & $\begin{array}{c}2.566^{* *} \\
*\end{array}$ & $1.172^{* *}$ & $\begin{array}{c}1.713^{* *} \\
*\end{array}$ \\
\hline & & & & & & $(0.939)$ & $(0.683)$ & $(0.549)$ & $(0.578)$ & $(0.568)$ \\
\hline \multirow[t]{3}{*}{ Labor_Force } & & & & & & & - & - & - & \\
\hline & & & & & & & $\begin{array}{l}0.057^{* *} \\
*\end{array}$ & $\begin{array}{c}0.054^{* *} \\
*\end{array}$ & $\begin{array}{c}0.077^{* *} \\
*\end{array}$ & \\
\hline & & & & & & & $(0.020)$ & $(0.018)$ & $(0.020)$ & \\
\hline \multirow[t]{2}{*}{ Unemployment } & & & & & & & 0.029 & $0.050^{* *}$ & $0.058^{* *}$ & $\begin{array}{c}0.085^{* *} \\
*\end{array}$ \\
\hline & & & & & & & $(0.029)$ & $(0.024)$ & $(0.026)$ & $(0.027)$ \\
\hline \multirow[t]{3}{*}{ Gov_GDP } & & & & & & & & - & - & - \\
\hline & & & & & & & & $\begin{array}{c}0.107^{* * *} \\
*\end{array}$ & $0.101^{* *}$ & $\begin{array}{c}0.176^{* *} \\
*\end{array}$ \\
\hline & & & & & & & & $(0.036)$ & $(0.042)$ & $(0.043)$ \\
\hline \multirow{2}{*}{$\begin{array}{l}\text { Fin_Dev*Econ_Gl } \\
\mathrm{ob}\end{array}$} & & & & & & & & & 1.189 & \\
\hline & & & & & & & & & $(3.897)$ & \\
\hline \multirow{2}{*}{$\begin{array}{l}\text { Fin_Dev*Econ_Gl } \\
\mathrm{ob}^{\wedge} 2\end{array}$} & & & & & & & & & 4.473 & \\
\hline & & & & & & & & & $(4.481)$ & \\
\hline Fin_Open & & & & & & & & & & $\begin{array}{c}0.027 \\
(0.115)\end{array}$ \\
\hline \multirow[t]{2}{*}{ Real_Trade_Open } & & & & & & & & & & $\begin{array}{c}0.020^{* *} \\
*\end{array}$ \\
\hline & & & & & & & & & & $(0.007)$ \\
\hline \multirow[t]{2}{*}{ Sabit } & $\begin{array}{c}29.435^{*} \\
* *\end{array}$ & $\begin{array}{c}31.865^{*} \\
* *\end{array}$ & $\begin{array}{l}30.724^{*} \\
* *\end{array}$ & $\underset{* *}{29.244^{*}}$ & $\begin{array}{c}38.620^{*} \\
* *\end{array}$ & $\begin{array}{c}47.638^{*} \\
* *\end{array}$ & $\underset{* *}{44.866^{*}}$ & $\underset{* *}{44.315^{*}}$ & $\begin{array}{c}38.679 * \\
* *\end{array}$ & $\begin{array}{c}37.574^{*} \\
* *\end{array}$ \\
\hline & $(0.671)$ & $(1.606)$ & $(1.493)$ & $(2.151)$ & $(5.571)$ & $(8.763)$ & $(6.429)$ & (6.534) & $(4.565)$ & $\begin{array}{c}(11.078 \\
)\end{array}$ \\
\hline R2 (Within) & 0.0983 & 0.1331 & 0.2513 & 0.2574 & 0.2638 & 0.2783 & 0.2972 & 0.3092 & 0.2408 & 0.2716 \\
\hline Gözlem Sayısı & 756 & 756 & 756 & 756 & 756 & 756 & 756 & 756 & 756 & 756 \\
\hline Ülke Sayısı & 27 & 27 & 27 & 27 & 27 & 27 & 27 & 27 & 27 & 27 \\
\hline
\end{tabular}

Not: $\% 10, * * \% 5$ ve **\%1 düzeylerindeki anlamlllk derecelerini göstermektedir. Tüm modellerde sabit etkili panel veri yöntemine bağlı regresyon sonuçları temelinde elde edilen kümelenmiş dirençli standart hatalar parantez içerisinde belirtilmektedir. 
Bu ampirik sonuç özellikle ana akım yazının ekonomik küreselleşmenin toplam gelirin bölüşümünü olumlu yönde etkilediği varsayımı ile çelişmesi nedeniyle ayrı bir teorik anlama sahip bulunmaktadır. Diğer tüm modellerde de bu olgunun istatistiksel olarak anlamlılığını koruduğu görülmektedir. Model 4 'te refah temelli toplam faktör verimliliği (TFP) endeksi regresyon analizine dahil edilmektedir. TFP endeksinin gelir eşitsizliğini artırdığı görülmekte ve ayrıca ilgili sonuçlar çerçevesinde bu durumun ardında teknolojide yaşanan ilerlemeler nedeniyle en alt gelir grubunda yer alan hanehalkı kesiminin istihdamdan uzak kalarak gelir elde etmekten mahrum kaldığı ve toplam gelirin en üst gelir grubuna ait hanehalkı kesimine yöneldiği varsayımı kabul edilmektedir. Model 5'te ise ekonomik kalkınmanın gelir eşitsizliği üzerindeki etkisini ölçmek için logaritmik ölçekte hesaplanan kişi başına GSYH (Log(GDPperCap)) değiş̧keni vekil değişken olarak analize dahil edilmektedir. Ampirik sonuçlar ekonomik gelişmedeki artışın toplumda gelirin daha yüzeysel ve eşit bir biçimde dağılmasına yol açarak toplam eşitsizliğin azaldığını göstermektedir. Bu açıdan geleneksel görüşler ile aynı düzlemde bulunmakta ve ekonomik gelişmenin bölüşüm için önemini ortaya koymaktadır. Model 6 ve Model 7'de ise emek piyasalarına ait değişkenler regresyon analizine dahil edilmektedir. İlk olarak, beşeri sermaye (Human_Cap) düzeyindeki artışın çalışan kesim içerisinde çalışanların vasıflarındaki farklılıklar temelinde gelir eşitsizliğini olumsuz yönde etkilediği görülmektedir. Aynı şekilde, işsizlik oranındaki (Unemployment) artışında gelir eşitsizliğini çalışanların sermaye karşısında pazarlık güçlerini olumsuz etkilemesi nedeniyle artırdığı görülmektedir. Son olarak, işgücüne katılım oranının (Labor_Force) ise gelir eşitsizliğini büyük oranda azalttığı çıkan sonuçlar çerçevesinde belirtilebilir. Bu olgu basit olarak istihdam da yer alan çal1şan sayısının artmasının gelirlere erişimi sağlayarak toplumun büyük oranda her kesiminin gelir sahibi olması ile sonuçlanmaktadır. Bu nedenle, gelir eşitsizliğini mutlak olarak (görece olarak değil) azaltmaktadır. Model 8 ise GSYH'nın bir payı olarak devlet harcama miktarı (Gov_GDP) ile gelir eşitsizliği arasındaki ilişkinin sonuçlarını göstermektedir. Elde edilen ampirik bulgular devlet harcamalarının toplam ekonomi içerisinde ne kadar payı artarsa kaynaklara her kesimin ulaşımının artması çerçevesinde gelir eşitsizliğinin azaldığını vurgulamaktadır. Model 9 ve Model $10^{\prime}$ da ise sırasıyla finansal gelişme endeksi ve ekonomik küreselleşme 
endeksi değişkenleri ile oluşturulan etkileşim teriminin (Fin_Dev*Econ_Glob) ve ekonomik küreselleşme endeksini oluşturan finansal açılık (Fin_Open) ile reel ticari açıklık (Real_Trade_Open) vekil değişkenlerin gelir eşitsizliği üzerindeki bağımsız etkileri ele alınarak incelenmektedir. İlk olarak, Model 9 etkileşim teriminin ve onun karesinin iktisadi olarak ve finansal Kuznets hipotezi bağlamında önemli bir anlamı olduğunu göstermektedir. Elde edilen katsayılar etkileşim teriminin ekonomik gelişmenin ilk dönemlerinde gelir eşitsizliğini azaltıcı bir etkisinin bulunduğunu ama gelişim sürecinin tamamlanması ile gelir eşitsizliğinin tekrar artmaya başladığını göstermektedir. Bu olgunun iktisadi anlamda açılaması ise şu şekilde belirtilebilir: ilgili ülke örneklemi çerçevesinde finansal gelişme sağlanmadan ekonomik küreselleşmenin ilk dönemlerinde kaynaklara ulaşımın hızlanması ve her gelir grubunun bu kaynaklardan belirli oranlarda yararlanması sonucunda gelir eşitsizliğinde bir düşüş yaşanabilir. Ancak zaman içerisinde kaynakların tüm topluma yayılması ile bölüşüm yasaları tekrar alt gelir gruplarına yönelik şiddetlenerek gelir eşitsizliğini artırmaya neden olabilir. Diğer bir ifadeyle, ülkelerin ekonomik küreselleşme süreçleri finansal gelişme düzeyini takip etmektedir. Ancak finansal gelişmenin zaman içerisinde sağlanması dahi ekonomik küreselleşme ile bütünleşmesinde gelir eşitsizliğini artırıcı bir etkiye sahip bulunmaktadır. Model $10^{\prime}$ da ise ekonomik küreselleşme endeksine ait alt değişkenlerden reel ticaret açılığının gelir eşitsizliğini artırmada finansal açıklığa göre etkili olduğu görülmektedir.

Tablo 1'deki sonuçları ayrıca finansal kurumlar ve finansal piyasaların gelişme endeksleri temelinde ele alan Tablo 2 ve Tablo 3 'te ise finansal gelişmeye ait alt değişkenlerin gelir eşitsizliği üzerinde farklı etkilere sahip olduğu görülmektedir. İlk olarak, Tablo 1'deki sonuçlar ile benzerlikleri üzerinden yapılabilecek analizlerin başında ekonomik küreselleşmenin gelir eşitsizliğini artırıcı etkisinin devam etmesi belirtilebilir. Ayrıca, ilgili göstergenin hem finansal hem de ticari açılık alt göstergelerinin gelir eşitsizliği ile ilişkisinin test edildiği diğer bir regresyon tahmininde ise halen ticari açıklık finansal açıklığın aksine bölüşümü negatif etkilemektedir. Çalışan kesimin pazarlık gücünü tanımlayan değişkenlerinde Tablo 1'deki değişkenlere ait katsayılara benzer içeriklere sahip olması gelir eşitsizliğindeki değişim hakkında daha detaylı bilgiler edinmemizi sağlamaktadır. Özellikle pazarlık gücünün beşeri sermaye ve işgücüne katılım 
oranına ait iki vekil değişkeninin ilgili istatistiksel ilişkilerin önemli belirleyenleri olarak öne çıktığı görülmektedir. Ancak aynı sonucu elde edilen sonuçlar temelinde işsizlik oranı için söylemek olanaklı değildir.

Bunun yanı sıra, devlet harcamaların GSYH içindeki artan payının gelir eşitsizliğini finansal alanının mikro bazlı analizlerinde de azaltma gücüne sahip olduğunu söylemek mümkündür. Teknolojik ilerlemenin ise öncelikli olarak istihdam edilme oranını aşağı çekmesi nedeniyle potansiyel olarak gelir eşitsizliğini artırdığı varsayımı Tablo 2 ve Tablo 3'teki katsayılar çerçevesinde finansal sektör gelişiminin alt değişkenlerine bağlı analiz kapsamında da geçerliğini korumaktadır. Son olarak, gelirin adil bölüşümünü tetikleyen pozitif etkili ekonomik gelişme değişkeninin ilgili analiz başlıkları altında da geçerli olduğu söylenebilir.

Ancak bu benzerliklerin aksine, Tablo 2' de finansal kurumlar gelişme değişkeni ile gelir eşitsizliği arasındaki analiz sonuçları ters U-ilişkili finansal Kuznets hipotezinin varlığını istatistiksel olarak doğrularken, finansal piyasalar gelişme değişkeni ile gelir eşitsizliği temelinde elde edilen Tablo 3'teki analiz sonuçları U-ilişkili finansal Kuznets hipotezinin istatistiksel olarak kabul edilmesi gerektiğini göstermektedir. Bu açıdan, finansal Kuznets hipotezinin hangi açıdan değerlendirilmesi ve yorumlanması gerektiği literatürde var olan çalışmaların birçoğuna referans vererek açılanabilmektedir. 
Finansal Kuznets Eğrisi ve Ekonomik Küreselleşme İlişkisi Üzerine: OECD Ülkeleri İçin Gelir Eşitsizliği Temelli Bir Analiz

Tablo 2. Sabit Etkiler Yöntemine Bağlı Regresyon Sonuçları (Finansal Kurumlar Gelişme Endeksi Temelinde)

\begin{tabular}{|c|c|c|c|c|c|c|c|c|c|c|}
\hline & (1) & (2) & (3) & (4) & (5) & (6) & (7) & (8) & (9) & (10) \\
\hline Fin_Inst & $0.025^{*}$ & $0.015^{*}$ & 0.006 & 0.003 & 0.007 & $0.011^{* * *}$ & $\begin{array}{c}0.013^{* *} \\
*\end{array}$ & $\begin{array}{c}0.013^{* *} \\
*\end{array}$ & & -0.001 \\
\hline & $(0.014)$ & $(0.008)$ & $(0.005)$ & $(0.006)$ & $(0.004)$ & $(0.004)$ & $(0.004)$ & $(0.004)$ & & $(0.006)$ \\
\hline Fin_Inst ${ }^{\wedge} 2$ & & 0.016 & -0.011 & $0.014^{* *}$ & -0.010 & $\begin{array}{c}- \\
0.020^{* * *} \\
*\end{array}$ & $\begin{array}{c}- \\
0.019^{* *} \\
*\end{array}$ & $\begin{array}{c}- \\
0.019^{* *} \\
*\end{array}$ & & 0.001 \\
\hline & & $(0.010)$ & $(0.007)$ & $(0.006)$ & $(0.008)$ & $(0.007)$ & $(0.006)$ & $(0.006)$ & & $(0.007)$ \\
\hline Econ_Glob & & & $\begin{array}{l}0.062^{* *} \\
* \\
(0.006)\end{array}$ & $\begin{array}{l}0.064^{* *} \\
* \\
(0.007)\end{array}$ & $\begin{array}{l}0.077^{* *} \\
* \\
(0.009)\end{array}$ & $\begin{array}{l}0.076^{* *} \\
* \\
(0.008)\end{array}$ & $\begin{array}{c}0.068^{* *} \\
* \\
(0.006)\end{array}$ & $\begin{array}{l}0.065^{* *} \\
* \\
(0.007)\end{array}$ & & \\
\hline TFP & & & & $2.378^{*}$ & $3.376^{* *}$ & $\begin{array}{c}5.293^{* *} \\
*\end{array}$ & $\begin{array}{c}4.626^{* *} \\
*\end{array}$ & $\begin{array}{l}4.664^{* *} \\
*\end{array}$ & 1.629 & $3.606^{* *}$ \\
\hline & & & & $(1.254)$ & $(1.452)$ & $(1.642)$ & $(1.595)$ & $(1.580)$ & $(1.099)$ & $(1.753)$ \\
\hline Log(GDPperCap) & & & & & $-2.842^{*}$ & $\begin{array}{c}- \\
7.676^{* *}\end{array}$ & $\begin{array}{c}- \\
6.471^{* *} \\
*\end{array}$ & ${ }^{-} \cdot 314^{* *}$ & -0.711 & -2.250 \\
\hline & & & & & $(1.619)$ & (3.126) & (2.306) & $(2.323)$ & $(2.023)$ & $(3.070)$ \\
\hline Human_Cap & & & & & & $\begin{array}{c}2.583^{* *} \\
* \\
(0.892)\end{array}$ & $\begin{array}{c}2.531^{* *} \\
* \\
(0.561)\end{array}$ & $\begin{array}{c}2.711^{* *} \\
* \\
(0.513)\end{array}$ & $\begin{array}{c}1.709^{* *} \\
* \\
(0.530)\end{array}$ & $\begin{array}{c}1.870^{* *} \\
* \\
(0.659)\end{array}$ \\
\hline Labor_Force & & & & & & & $\stackrel{-}{-}$ & $\stackrel{-}{-}$ & $\begin{array}{c}- \\
0.079^{* *} \\
*\end{array}$ & \\
\hline & & & & & & & $(0.022)$ & $(0.021)$ & $(0.018)$ & \\
\hline Unemployment & & & & & & & $\begin{array}{c}0.009 \\
(0.035)\end{array}$ & $\begin{array}{c}0.018 \\
(0.031)\end{array}$ & $\begin{array}{l}0.059^{* * *} \\
(0.030)\end{array}$ & $\begin{array}{l}0.064^{* *} \\
(0.026)\end{array}$ \\
\hline Gov_GDP & & & & & & & & -0.050 & $\begin{array}{c}- \\
0.106^{* *} \\
*\end{array}$ & - \\
\hline & & & & & & & & $(0.046)$ & $(0.042)$ & $(0.054)$ \\
\hline $\begin{array}{l}\text { Fin_Inst }{ }^{*} \text { Econ_Glo } \\
\mathrm{b}\end{array}$ & & & & & & & & & $\begin{array}{l}-3.141 \\
(6.716)\end{array}$ & \\
\hline $\begin{array}{l}(\text { Fin_InstEcon_Gl } \\
\mathrm{ob})^{\wedge} 2\end{array}$ & & & & & & & & & $\begin{array}{l}8.323 \\
(5.924)\end{array}$ & \\
\hline Fin_Open & & & & & & & & & & $\begin{array}{l}-0.091 \\
(0.097)\end{array}$ \\
\hline Real_Trade_Open & & & & & & & & & & $\begin{array}{c}0.021^{* *} \\
* \\
(0.008)\end{array}$ \\
\hline Sabit & $\begin{array}{c}30.057 \\
* * * \\
(1.042)\end{array}$ & $\begin{array}{c}30.028 \\
* * * \\
(0.972)\end{array}$ & $\begin{array}{c}27.565 \\
* * * \\
(0.850)\end{array}$ & $\begin{array}{c}25.518 \\
* * * \\
(1.578)\end{array}$ & $\begin{array}{c}35.707 \\
* * * \\
(6.021)\end{array}$ & $\begin{array}{c}47.465 \\
* * * * \\
(9.866)\end{array}$ & $\begin{array}{c}46.650 \\
* * * \\
(7.107)\end{array}$ & $\begin{array}{c}46.388 \\
* * * \\
(7.173)\end{array}$ & $\begin{array}{c}33.713 \\
* * * \\
(6.626)\end{array}$ & $\begin{array}{c}33.466 \\
* * * \\
(11.081 \\
)\end{array}$ \\
\hline R2 (Within) & 0.0390 & 0.0452 & 0.1829 & 0.1963 & 0.2035 & 0.2220 & 0.2372 & 0.2400 & 0.2207 & 0.1981 \\
\hline Gözlem Sayısı & 756 & 756 & 756 & 756 & 756 & 756 & 756 & 756 & 756 & 756 \\
\hline Ülke Sayısı & 27 & 27 & 27 & 27 & 27 & 27 & 27 & 27 & 27 & 27 \\
\hline
\end{tabular}


Tablo 3. Sabit Etkiler Yöntemine Bağh Regresyon Sonuçları

(Finansal Piyasalar Gelişme Endeksi Temelinde)

\begin{tabular}{|c|c|c|c|c|c|c|c|c|c|c|}
\hline & (1) & (2) & (3) & (4) & (5) & (6) & (7) & (8) & (9) & (10) \\
\hline \multirow[t]{4}{*}{ Fin_Mar } & $0.028^{* *}$ & 0.009 & - & - & - & - & - & - & & -0.018 \\
\hline & * & & $0.032^{* *}$ & $0.031^{* *}$ & $0.027^{* *}$ & $0.033^{* *}$ & $0.032^{* *}$ & $0.034^{* *}$ & & \\
\hline & & & $*$ & * & * & * & * & * & & \\
\hline & $(0.005)$ & $(0.016)$ & $(0.010)$ & $(0.009)$ & $(0.007)$ & $(0.009)$ & $(0.011)$ & $(0.010)$ & & $(0.017)$ \\
\hline \multirow[t]{2}{*}{ Fin_Mar^2 } & & 0.019 & $\begin{array}{c}0.043^{* *} \\
*\end{array}$ & $\begin{array}{c}0.041^{* *} \\
*\end{array}$ & $\begin{array}{c}0.041^{* *} \\
*\end{array}$ & $\begin{array}{c}0.045^{* *} \\
*\end{array}$ & $\begin{array}{c}0.045^{* *} \\
*\end{array}$ & $\begin{array}{l}0.047^{* *} \\
*\end{array}$ & & $0.035^{*}$ \\
\hline & & $(0.016)$ & $(0.013)$ & $(0.011)$ & $(0.010)$ & $(0.011)$ & $(0.011)$ & $(0.011)$ & & $(0.018)$ \\
\hline \multirow[t]{2}{*}{ Econ_Glob } & & & $\begin{array}{c}0.051^{* *} \\
*\end{array}$ & $\begin{array}{c}0.051^{* *} \\
*\end{array}$ & $\begin{array}{c}0.075^{* *} \\
*\end{array}$ & $\begin{array}{c}0.075^{* *} \\
*\end{array}$ & $\begin{array}{c}0.066^{* *} \\
*\end{array}$ & $\begin{array}{c}0.062^{* *} \\
*\end{array}$ & & \\
\hline & & & $(0.012)$ & $(0.012)$ & $(0.010)$ & $(0.009)$ & $(0.008)$ & $(0.007)$ & & \\
\hline \multirow[t]{2}{*}{ TFP } & & & & 0.964 & $2.838^{* *}$ & $4.066^{* *}$ & $3.573^{* *}$ & $3.616^{* *}$ & 1.617 & $2.982^{*}$ \\
\hline & & & & $(0.987)$ & $(1.354)$ & $(1.518)$ & $(1.547)$ & $(1.530)$ & (1.153) & (1.634) \\
\hline \multirow[t]{3}{*}{ Log(GDPperCap) } & & & & & - & - & - & - & -1.027 & -3.356 \\
\hline & & & & & $\begin{array}{l}4.557^{* *} \\
*\end{array}$ & $\begin{array}{c}7.658^{* *} \\
*\end{array}$ & $\begin{array}{c}5.998^{* *} \\
*\end{array}$ & $5.828^{* *}$ & & \\
\hline & & & & & $(1.441)$ & $(2.704)$ & $(2.144)$ & $(2.106)$ & $(1.724)$ & (3.056) \\
\hline \multirow[t]{2}{*}{ Human_Cap } & & & & & & $1.676^{*}$ & $1.472^{*}$ & $1.726^{* *}$ & $1.339^{* *}$ & $1.099^{*}$ \\
\hline & & & & & & $(0.964)$ & $(0.717)$ & $(0.652)$ & $(0.637)$ & $(0.642)$ \\
\hline \multirow[t]{3}{*}{ Labor_Force } & & & & & & & - & - & - & \\
\hline & & & & & & & $0.056^{* *}$ & $0.055^{* *}$ & $\begin{array}{l}0.077^{* *} \\
*\end{array}$ & \\
\hline & & & & & & & $(0.022)$ & $(0.020)$ & $(0.021)$ & \\
\hline \multirow[t]{2}{*}{ Unemployment } & & & & & & & 0.025 & 0.038 & $0.054^{* *}$ & $\begin{array}{c}0.073^{* *} \\
*\end{array}$ \\
\hline & & & & & & & $(0.031)$ & $(0.026)$ & $(0.026)$ & $(0.025)$ \\
\hline \multirow[t]{3}{*}{ Gov_GDP } & & & & & & & & $-0.068^{*}$ & - & - \\
\hline & & & & & & & & & $0.099^{* *}$ & $\begin{array}{c}0.141^{* *} \\
*\end{array}$ \\
\hline & & & & & & & & $(0.038)$ & $(0.051)$ & $(0.050)$ \\
\hline Fin_Mar*Econ_Glo & & & & & & & & & $2.559^{* *}$ & \\
\hline \multirow[t]{2}{*}{$\mathrm{b}$} & & & & & & & & & * & \\
\hline & & & & & & & & & $(0.910)$ & \\
\hline \multirow{2}{*}{$\begin{array}{l}(\text { Fin_Mar*Econ_Gl } \\
\mathrm{ob})^{\wedge} 2\end{array}$} & & & & & & & & & 0.960 & \\
\hline & & & & & & & & & & \\
\hline Fin_Open & & & & & & & & & & $\begin{array}{l}-0.013 \\
(0.118)\end{array}$ \\
\hline \multirow[t]{2}{*}{ Real_Trade_Open } & & & & & & & & & & $\begin{array}{c}0.021^{* *} \\
*\end{array}$ \\
\hline & & & & & & & & & & $(0.007)$ \\
\hline \multirow[t]{3}{*}{ Sabit } & 30.294 & 30.701 & 28.602 & 27.649 & 44.124 & 51.663 & 49.147 & 48.967 & 35.539 & 40.995 \\
\hline & $* * *$ & $* * *$ & $* * *$ & $* * *$ & $* * *$ & $* * *$ & $* * *$ & $* * *$ & $* * *$ & $* * *$ \\
\hline & $(0.304)$ & $(0.481)$ & $(0.827)$ & $(1.486)$ & $(5.245)$ & $(8.260)$ & $(6.103)$ & $(6.069)$ & $(5.789)$ & $\begin{array}{c}(11.044 \\
)\end{array}$ \\
\hline $\mathrm{R}^{2}$ (Within) & 0.1392 & 0.1431 & 0.2212 & 0.2235 & 0.2451 & 0.2530 & 0.2708 & 0.2759 & 0.2292 & 0.2446 \\
\hline Gözlem Sayısı & 756 & 756 & 756 & 756 & 756 & 756 & 756 & 756 & 756 & 756 \\
\hline Ülke Sayısı & 27 & 27 & 27 & 27 & 27 & 27 & 27 & 27 & 27 & 27 \\
\hline
\end{tabular}

Not: $\% 10, * * \% 5$ ve ***\%1 düzeylerindeki anlamlllı derecelerini göstermektedir. Tüm modellerde sabit etkili panel veri yöntemine bağlı regresyon sonuçları temelinde elde edilen kümelenmiş dirençli standart hatalar parantez içerisinde belirtilmektedir. 


\section{Sistem-GMM Yaklaşımına Bağlı Analiz Sonuçları}

Mevcut çalışma ayrıca dinamik panel veri analizi çerçevesinde değişkenler arasındaki korelasyonları belirlemek ve test etmek için Sistem-GMM tahmincisini kullanmaktadır. Bu bağlamda, bağımsız değişkenler ile hata terimi arasında potansiyel bir korelasyonun varlığı göz önünde bulundurularak gecikmesi alınmış bağımlı değişkenin içselliği kontrol edilmektedir. Aynı zamanda Sistem-GMM yaklaşımı sayesinde dışlanmış değişken yanlılığı, gözlemlenemeyen panel heterojenliği ve ölçüm hataları düzeltilmiş olur. İlgili sorunların çözümü kapsamında dinamik panel veri yaklaşımına bağlı olarak elde edilen katsayı tahminleri araç değişken sayısının dışsal ve gözlem sayısından daha az olması gereken teknik gereksinimleri şart koşmaktadır. Son olarak, ilgili çalışmada sabit etkiler yöntemine bağlı katsayı tahminlerinde ortaya çıabilecek sorunları çözmek için SistemGMM tahmincisinden yararlanılmaktadır. Bazı temel sorunlar kısaca şu şekilde sıralanabilir: (i) bağımsız değişkenler arasında katı bir dışsallığın olmaması, (ii) rastgele dağıtılmış sabit etkiler, (iii) heterojenlik ve (iv) paneller arasinda seri korelasyon durumu.

Sıralanan teknik problemler göz önünde tutularak ilgili çalışma, veri seti gözlem sayısının yüksek olduğu ancak zaman boyutu açısından belirli bir kısıtı içeren ve idiyosenkratik hata terimin otokorelasyondan bağımsız olduğu bir dinamik panel veri analizi çerçevesinde katsayı tahminlerine ulaşmaktadır. Bu nedenle, Sistem-GMM tahmincisinin seçili paneller için dayanıklı tahminci katsayıları sağladığı varsayılmaktadır. Arellano ve Bond (1991) tarafından önerilen ortogonallik koşullarını analiz etmek için hem Hansen (1982) J-testi hem de hata teriminin ikinci dereceden seri korelasyonunu analiz etmek için AR(2) testi Sistem-GMM yaklaşımının sonuçlarının aktarıldığı Tablo 4'te verilmektedir. Bu açıdan Tablo 4'te elde edilen ampirik sonuçlara bağlı olarak, seri korelasyonun ikinci derecede var olmadığı ve aşırı tanımlayıcı kısıtlamaların J-testi açısından reddedilemediği söylenebilir. Böylece analiz sonuçları herhangi istatistiki bir sorunun olmadığını göstermektedir.

Tablo 4 içerisindeki ampirik bulgular finansal sektör gelişimi ile ilgili değişkenlerin katsayılarının ekonomik gelişmenin ilk dönemlerinde gelir eşitsizliğini azalttığı ileri dönemlerde ise ekonomik gelişmenin toplumun tümüne yayılmaya başladığı zamanlarda arttığını göstermektedir. Tek bir 
istisna olarak finansal kurumlar gelişme endeksine ait değişkenin tam tersi sonuçlar sergilediği görülmektedir.

Tablo 4. Sistem-GMM Yaklaşımına Bağlı Regresyon Sonuçları

\begin{tabular}{|c|c|c|c|c|c|c|}
\hline & $(1)$ & $(2)$ & (3) & $(4)$ & (5) & (6) \\
\hline L.Gini & $\begin{array}{c}0.854^{* * *} \\
(0.026)\end{array}$ & $\begin{array}{c}0.821^{* * *} \\
(0.036)\end{array}$ & $\begin{array}{c}0.829^{* * * *} \\
(0.038)\end{array}$ & $\begin{array}{c}0.856^{* * *} \\
(0.035)\end{array}$ & $\begin{array}{c}0.823^{* * *} \\
(0.042)\end{array}$ & $\begin{array}{c}0.850^{* * * *} \\
(0.045)\end{array}$ \\
\hline L.Fin_Dev & $\begin{array}{c}-0.153^{* * *} \\
(0.028)\end{array}$ & & & & & \\
\hline L.Fin_Dev ${ }^{\wedge} 2$ & $\begin{array}{c}0.111^{* * *} \\
(0.023)\end{array}$ & & & & & \\
\hline L.Fin_Inst & & $\begin{array}{l}-0.003 \\
(0.007)\end{array}$ & & & & \\
\hline L.Fin_Inst ${ }^{\wedge} 2$ & & $\begin{array}{c}-0.015^{* * *} \\
(0.005)\end{array}$ & & & & \\
\hline L.Fin_Mar & & & $\begin{array}{c}-0.037^{* * *} \\
(0.014)\end{array}$ & & & \\
\hline L.Fin_Mar^2 & & & $\begin{array}{c}0.025^{*} \\
(0.013)\end{array}$ & & & \\
\hline L.Fin_Dev*Econ_Glob & & & & $\begin{array}{c}-11.387^{* *} \\
(4.568)\end{array}$ & & \\
\hline L.(Fin_Dev*Econ_Glob)^2 & & & & $\begin{array}{c}10.852^{* *} \\
(4.761)\end{array}$ & & \\
\hline L.Fin_Inst*Econ_Glob & & & & & $\begin{array}{c}-13.958^{* * *} \\
(4.808)\end{array}$ & \\
\hline L.(Fin_Inst*Econ_Glob)^2 & & & & & $\begin{array}{c}11.791^{* *} \\
(5.009)\end{array}$ & \\
\hline L.Fin_Mar*Econ_Glob & & & & & & $\begin{array}{l}-4.857 \\
(3.453)\end{array}$ \\
\hline L.(Fin_Mar*Econ_Glob)^2 & & & & & & $\begin{array}{c}4.117 \\
(4.092)\end{array}$ \\
\hline Sabit & $\begin{array}{c}9.623^{* * *} \\
(1.346)\end{array}$ & $\begin{array}{c}6.862^{* * *} \\
(0.832)\end{array}$ & $\begin{array}{c}6.807^{* * *} \\
(1.106)\end{array}$ & $\begin{array}{c}7.377^{* * *} \\
(1.351)\end{array}$ & $\begin{array}{l}9.518^{* * *} \\
(2.013)\end{array}$ & $\begin{array}{c}6.089^{* * * *} \\
(1.169)\end{array}$ \\
\hline $\operatorname{AR}(1)$ & 0.000 & 0.000 & 0.000 & 0.000 & 0.001 & 0.000 \\
\hline $\operatorname{AR}(2)$ & 0.143 & 0.607 & 0.225 & 0.275 & 0.806 & 0.255 \\
\hline Hansen $J$ Testi & 0.342 & 0.549 & 0.555 & 0.227 & 0.068 & 0.376 \\
\hline Wald $\chi^{2}$ (p-değeri) & 0.000 & 0.000 & 0.000 & 0.000 & 0.000 & 0.000 \\
\hline Araç Değişken Sayısı & 12 & 25 & 25 & 19 & 19 & 19 \\
\hline Gözlem Sayısı & 675 & 675 & 675 & 675 & 675 & 675 \\
\hline Ülke Sayısı & 27 & 27 & 27 & 27 & 27 & 27 \\
\hline
\end{tabular}

Not: $\% 10, * * \% 5$ ve ***1 düzeylerindeki anlamlılı derecelerini göstermektedir. Tüm modellerde Arellano ve Bover (1995) ve Blundell ve Bond (1998) tarafindan üretilen, Roodman (2006) tarafindan uygulanan iki aşamalı Sistem-GMM yaklaşımı uygulanmaktadır. Ayrıca Windmeijer (2005) tarafından geliştirilen dayanıklı standart hatalar kullanılmaktadır. Hansen J-testi istatistikleri aşırı belirleme kısıtlamalarının geçerli olup olmadığını belirtmek için model sonuçları olarak verilmektedir. Tüm Sistem-GMM yaklaşımına bağlı elde edilen regresyon sonuçları çok sayıda araç değişken problemini çözmek ve ortogonallik koşullarını sağlamak için "collapse" yöntemi çerçevesinde elde edilmiştir. Ortak sıfır hipotezi kullanılan enstrümanların geçerli enstrümanlar olduğunu, yani hata terimi ile ilişkisiz olduklarını ve hariç tutulan enstrümanların tahmin edilen denklemden doğru şekilde çıkarıldığını göstermektedir. AR(2)'nin sonuçları uygun maksimum gecikme sayısı durumunda otokorelasyonun kontrol edilmesi için sağlanmaktadır. 
$\mathrm{Bu}$ çerçevede hem finansal sektör gelişme endeksi hem de finansal piyasalar gelişme değişkeninin Gini katsayısı ile arasında pozitif bir ilişkinin varlığı mevcut bulunmaktadır. Diğer bir ifadeyle, her iki değişkene bağlı sonuçlar U-ilişkili finansal Kuznets hipotezinin geçerliliğine vurgu yapmaktadır. Ayrıca Tablo 4, finansal gelişme endeksi ve ekonomik küreselleşme değişkeni ile oluşturulan etkileşim terimi ve gelir eşitsizliği arasındaki ilişkiye ait katsayıları da vermektedir.

Çıkan sonuçlar finansal gelişmenin ekonomik küreselleşme ile sağlanmamasının ekonomik gelişmenin ileri dönemlerinde gelir eşitsizliğini artıracağını göstermektedir. Bu açıdan ikili arasında koşullu bir ilişkinin var olduğu görülmektedir.

\section{Sonuç}

Bu çalışma finansal Kuznets hipotezinin teorik arka planını, finansal sektör gelişimi ile gelir eşitsizliği arasındaki ilişki açısından test etmektedir. Finansal sektör gelişimine ait genel ve alt değişkenler çerçevesindeki modellemeler finans alanındaki daha yüksek bir gelişim düzeyinin gelir eşitsizliğinde artışa yol açtığını istatistiksel olarak doğrulamaktadır. Toplam ulusal gelirin farklı hanehalkı grupları arasında sosyal ve toplumsal olarak paylaşılması göz önünde bulundurularak ekonomik kalkınmanın ilk dönemlerinde farklı gelir düzeylerinde bulunan hanehalkları arasındaki gelir payı eşitsizliğinin azaldığı ancak ileri dönemlerde bu olgunun tersine dönerek aradaki payın üst gelir gruplarına doğru gelir eşitsizliğinin artması temelinde yöneldiği görülmektedir. Diğer bir ifadeyle, ampirik sonuçlar ana akım çalışmaların sunduğu temellerin ve teorik çıkarımların aksine finansal sektör gelişimi ile gelir eşitsizliği arasında pozitif ve istatistiksel olarak anlamlı bir ilişkinin olduğunu göstermektedir. Ayrıca Bumann ve Lensink (2016) tarafından belirtildiği gibi finansal hesabı ve ticaret rejimini kapsayan açıklık göstergeleri açısından daha yüksek düzeyde ekonomik küreselleşmenin belirtilen örneklemler çerçevesinde ulusal düzeyde benimsenmesinin ana akım görüşlerin tersine gelir eşitsizliğini artırıcı etkisinin bulunduğu söylenebilir. Bu açıdan değerlendirilirse daha yüksek düzeydeki bir ekonomik küreselleşme standardının benimsenmesi alt ve üst gelir gruplarında yer alan hanehalkları arasındaki gelir 
paylarının genişlemesine yol açarak gelir eşitsizliğinin artmasına neden olmaktadır. $\mathrm{Bu}$ istatistiksel ilişkinin ekonomik küreselleşmeyi betimleyen finansal ve ticari açıklık vekil değişkenlerinin kullanıldığı modellerde de geçerliliğini koruduğu görülmektedir (Haan vd., 2018). Son olarak, özellikle iki aşamalı Sistem-GMM yaklaşımı çerçevesinde elde edilen ampirik sonuçlar finansal gelişmenin ekonomik küreselleşme ile sağlanmamasının ekonomik gelişmenin ileri dönemlerinde gelir eşitsizliğini artıracağını göstermektedir. Bu nedenle hem ekonomik küreselleşme hem de finansal sektör gelişimi arasında gelirin bölüşümü açısından koşullu bir ilişkinin var olduğu görülmektedir. Tüm bu istatistiki olgular çerçevesinde belirtilebilir ki, mevcut çalışma ana akım literatürde varsayılan ters U-ilişkili finansal Kuznets hipotezi yerine U-ilişkili bir finansal Kuznets hipotezinin seçili örneklemler temelinde geçerli olduğu belirtmekte ve bu ilişkinin çok farklı kontrol değişkenlerinin kullanımı çerçevesinde istatistiki olarak geçerliliğini koruduğunu göstermektedir. 
EXTENDED ABSTRACT

\title{
On the Relationship Between Financial Kuznets Hy- pothesis and Economic Globalization: An Income In- equality Based Analysis for OECD Countries \\ *
}

\author{
Onur Özdemir \\ Istanbul Gelisim University
}

This study tests the theoretical background of the financial Kuznets hypothesis in terms of the relationship between financial sector development and income inequality. A bulk of studies on the basis of the relationship between the level of development in the financial sector and income inequality show that social groups experience a direct and indirect but a wide divergence in their income levels, in parallel with the changes in finance. However, there is still no consensus in the current literature for which variables together with corresponding socio-economic and political factors are much important than the rest of the others to determinate finance-income inequality nexus. In addition to that context, the dimensions of globalization are rarely included into the empirical investigations for a few of the related studies which of those examine the relationship between financial development and income inequality. In particular, within the framework of economic globalization, it should be considered that the financial openness indicator, which constitutes another pillar of financial development, should be included in the related finance-income inequality nexus. In that vein, the major point that distinguishes this study from the other studies in the literature is that it includes the phenomenon of economic globalization and other proxy variables in the empirical structure. In addition, another important point is that the investigation of the relationship between the financial Kuznets hypothesis and income inequality, the empirical analysis is carried out on the basis of variables covering all subcomponents of the financial sector. This is considered as an important dimension since the current literature takes into account a limited range of variables related to the measurement of financial development. In other words, financial sector development is examined separately through the use of three variables that include all sub-components of finance in terms 
of depth, access, and efficiency: (i) the weighted average of financial sector development index, (ii) financial institutions development index, and (iii) financial markets development index. Therefore, it can be argued that the investigation of financial Kuznets hypothesis in a broad analytical framework is somehow rare in the literature on the basis of financial sector development.

Within the framework of different perspectives on financial Kuznets hypothesis, one of the most important point of the current study that distinguishes it from the other studies is that it is based on a use of different empirical strategies and a wide range of country sample for financial sector development. Moreover, this study expands the findings of the relevant literature on a theoretical and hypothetical basis by including globalization indicators to point out another effect channel in the regression analysis, and hence it explores the effects of those variables on income distribution through the implementation of interaction variable between financial sector development and economic globalization indicators. In addition, the current study analyzes the relationship between income inequality and financial sector development, taking into account of the contradictions that arise in the production process. Therefore, it provides a priori information that will allow the empirical analysis performed at the individual income distribution framework to be considered under the assumptions of functional income distribution for further studies.

The sample of the study is based on OECD countries where the income levels of the countries concerned can be varied in terms of using different factors. However, these differences between those selected countries can affect the finance-income inequality nexus in the presence of conflicting interests among households through two aspects and thereby require an ample consideration. First, the segregation dynamics experienced in the redistribution of an aggregate income in different economic structures and household groups should be investigated by implementing various indicators covering economic, social, and financial factors together with an implementation of both short- and long-term comparisons. Second, many of the potential temporal effects of the development process on income distribution for financial markets and institutions should be examined by classifying them in terms of their economic positions across different countries. 
The motivation of this study is based on the implementation of counter arguments than the existing literature for the finance-income inequality nexus by considering the bargaining power indicators and the other factors which have an important role in production process. In other words, based on the theoretical and analytical misconceptions in the existing literature, it is assumed that the results of empirical analysis conducted on using of a large financial development database will reveal more comprehensive findings which reject the inverse U-shaped financial Kuznets hypothesis. Therefore, the current study will bring the group of variables used in the literature to measure the effect of financial development on income inequality to be tested in a wider domain. As a result, the empirical outputs to be found in this study show that the mainstream findings on the basis of inverse U-shaped financial Kuznets hypothesis can provide contrary evidence within the framework of measuring financial development with a wider set of variables. Thus, it can be concluded that the financial Kuznets hypothesis has a U-shaped structure along with the positions of the households in the production process in which they have heterogeneous characteristics. Following this context, the hypotheses regarding the financial development-income inequality nexus to be tested in the empirical analysis are conducted in terms of the following statements: (i) there is a long-term and positive relationship between income inequality and financial development, (ii) the interaction term of financial development and economic globalization has a negative relationship with income inequality in the early stages of economic development, but has a positive relationship in the latter periods, (iii) there is a long-term and positive relationship between economic globalization and income inequality, and (iv) there is a U-shaped correlation between income inequality and financial sector development, contrary to the findings of the mainstream literature in the context of the financial Kuznets hypothesis.

Within the framework of the above-mentioned hypotheses, the empirical study analyzes the relationship between financial development and income inequality for a sample of selected OECD member countries over the 1990-2017 period by using panel data analysis of fixed-effects method and the two-step system generalized method of moments (GMM) approach. In this sense, the current empirical approach is based on the analysis of within-country income inequality in terms of financial Kuznets 
hypothesis. The main rationale behing using the panel fixed effects method is to correct the relationship among the control variables and the disturbance term by excluding country-specific effects in the regression estimation. Furthermore, the current study implements the system-GMM approach to address the problems of reverse causality and omitted variable bias due to the reason that the fixed effects method of panel data does not fixed the endogeneity problem.

All in all, the models that constituted for overall context and the implementation of sub-variables of financial sector development statistically confirm that a higher level of development in finance leads to an increase in income inequality. In consideration of societal distribution of total national income among different income groups of households, it can be argued that the level of income inequality decreases in the early stages of economic development, but it turns to be a reverse in the latter periods on behalf of the top income groups of households. In other words, the empirical results show that there is a positive and statistically significant relationship between financial sector development and income inequality which contradict with the theoretical implications of mainstream studies. Moreover, as stated by Bumann and Lensink (2016), it can be stated that the adoption of economic globalization at the national level has an increasing effect on income inequality in terms of openness indicators covering both financial account and trade regime. From this point of view, the adoption of a higher level of economic globalization standard leads to an increase in income inequality among households. Furthermore, this statistical linkage maintains its presence in the models that use proxy variables for financial and trade openness. Finally, the empirical results also imply that the implementation of economic globalization without providing a stable development in financial sector increases the level of income inequality in the latter stages of economic development. For this reason, it can be argued that there is a conditional relationship between economic globalization and financial sector development in terms of income distribution. Within the framework of all these statistical findings, it can be stated that the current study provides an output that a U-shaped financial Kuznets hypothesis is valid on the basis of selected OECD countries and hence it statistically rejects the inverse U-shaped financial Kuznets hypothesis provided by the mainstream vision. 


\section{Kaynakça / References}

Aizenman, J., Jinjarak, Y. ve Park, D. (2015). Financial development and output growth in developing Asia and Latin America: A comparative sectoral analysis. NBER Working Paper 20917, National Bureau of Economic Research, Cambridge, Massachusetts.

Arellano, M. ve Bond, S. R. (1991). Some tests of specification for panel data: Monte Carlo evidence and an application to employment equations. Review of Economic Studies, 58, 277-297.

Arellano, M. ve Bover, O. (1995). Another look at the instrumental variable estimation of error-components models. Journal of Econometrics, 68, 2951.

Banerjee, A. V. ve Newman, A. F. (1993). Occupational choice and the process of development. Journal of Political Economy, 101, 274-298.

Blundell, R. ve Bond, S. (1998). Initial conditions and moment restrictions in dynamic panel data models. Journal of Econometrics, 87, 115-143.

Bumann, S. ve Lensink, R. (2016). Capital account liberalization and income inequality. Journal of International Money and Finance, 61, 143-162.

Chinn, M. D. ve Ito, H. (2006). What matters for financial development? Capital controls, institutions, and interactions. Journal of Development Economics, 81, 163-192.

Čihák, M., Demirgüç-Kunt, A., Feyen, E. ve Levine, R. (2012). Benchmarking financial development around the world. World Bank Policy Research Working Paper 6175, World Bank, Washington, DC.

de Haan, J. ve Sturm, J.-E. (2017). Finance and income inequality: A review and new evidence. European Journal of Political Economy, 50, 171-195.

de Haan, J., Pleninger, R. ve Sturm, J.-E. (2018). Does the impact of financial liberalization on income inequality depend on financial development? Some new evidence. Applied Economic Letters, 25, 313-316.

Driscoll, J. C. ve Kraay, A. C. (1998). Consistent covariance matrix estimation with spatially dependent panel data. Review of Economics and Statistics, 80, 549-560.

Galor, O. ve Zeira, J. (1993). Income distribution and macroeconomics. Review of Economic Studies, 60, 35-52.

Greenwood, J. ve Jovanovic, B. (1990). Financial development, growth, and the distribution of income. Journal of Political Economy, 98, 1076-1107.

Gygli, S., Haelg, F., Potrafke, N. ve Sturm, J-E. (2019). The KOF globalisation index - revisited. The Review of International Organizations, 14, 543-574. 
Hansen, L. P. (1982). Large sample properties of generalized method of moments estimators. Econometrica, 50, 1029-1054.

Jauch, S. ve Watzka, S. (2016). Financial development and income inequality: A panel data approach. Empirical Economics, 51, 291-314.

Jaumotte, F., Lall, S. ve Papageorgiou, C. (2008). Rising income inequality: Technology, or trade and financial globalization? IMF Working Paper 08/185, International Monetary Fund.

Kappel, V. (2010). The effects of financial development on income inequality and poverty. CER-ETH Economics Working Paper Series 10/127, CER-ETH Center of Economic Research (CER-ETH) at ETH Zurich.

Nikoloski, Z. (2012). Financial sector development and inequality: Is there a financial Kuznets curve? Journal of International Development, 25, 897911.

Rajan, R. G. (2010). Fault lines. Princeton: Princeton University Press.

Roodman, D. (2006). How to do xtabond2: an introduction to "difference" and "system" GMM in Stata. Center for Global Development, Working Paper Number 103, December.

Solt, F. (2016). The standardized world income inequality database. Social Science Quarterly, 97(5): 1267-1281.

Solt, F. (2020). Measuring income inequality across countries and over time: The standardized world income inequality database. Social Science Quarterly, 101(3): 1183-1199.

Svirydzenka, K. (2016). Introducing a new broad-based index of financial development. IMF Working Paper 16/5, International Monetary Fund.

Tan, H. B. ve Law, S. H. (2012). Nonlinear dynamics of the finance-inequality nexus in developing countries. Journal of Economic Inequality, 10, 551563.

Windmeijer, F. (2005). A finite sample correction for the variance of linear efficient two-step GMM estimators. Journal of Econometrics, 126, 25-51.

EK

Tablo A1. Veri Kaynakları ve Açıklamaları

\begin{tabular}{lll}
\hline Kısaltma & Değişken & Kaynak \\
\hline Gini & Gini Katsayısı & Solt (2020) \\
\hline Fin_Dev & $\begin{array}{l}\text { Ağırlıklı Ortalaması Alınmış Finansal Sektör } \\
\text { Gelişme Endeksi }\end{array}$ & IMF Veri Tabanı \\
\hline Fin_Dev^2 & Ağırlıklı Ortalaması Alınmış Finansal Sektör & $\begin{array}{l}\text { IMF Veri Tabanı; Yazarın Hesapla- } \\
\text { ması }\end{array}$ \\
\hline Fin_Inst & Gelişme Endeksi Karesi & IMF Veri Tabanı \\
\hline
\end{tabular}


Finansal Kuznets Eğrisi ve Ekonomik Küreselleşme İlişkisi Üzerine: OECD Ülkeleri İçin Gelir Eşitsizliği Temelli Bir Analiz

\begin{tabular}{|c|c|c|}
\hline Fin_Inst^2 & Finansal Kurumlar Gelişme Endeksi Karesi & $\begin{array}{l}\text { IMF Veri Tabanı; Yazarın Hesapla- } \\
\text { ması }\end{array}$ \\
\hline Fin_Mar & Finansal Piyasalar Gelişme Endeksi & IMF Veri Tabanı \\
\hline Fin_Mar^2 & Finansal Piyasalar Gelişme Endeksi Karesi & $\begin{array}{l}\text { IMF Veri Tabanı; Yazarın Hesapla- } \\
\text { ması }\end{array}$ \\
\hline Econ_Glob & Ekonomik Küreselleşme Endeksi & KOF Globalisation Index \\
\hline TFP & $\begin{array}{l}\text { Refah Temelli Toplam Faktör Üretkenliği En- } \\
\text { deksi }(2011=1)\end{array}$ & Penn World Tables 9.1 \\
\hline Log(GDPperCap) & $\begin{array}{l}\text { Logaritmik Ölçekte Kişi Başına GSYH } \\
\text { (2010\$ Sabit Fiyat) }\end{array}$ & $\begin{array}{l}\text { World Bank World Development } \\
\text { Indicators Veri Tabanı }\end{array}$ \\
\hline Human_Cap & Beşeri Sermaye Endeksi & Penn World Tables 9.1 \\
\hline Labor_Force & $\begin{array}{l}\text { İşgücü Katılım Oranı (\% +15 Yaş Üstü Top- } \\
\text { lam Nüfus) }\end{array}$ & $\begin{array}{l}\text { World Bank World Development } \\
\text { Indicators Veri Tabanı }\end{array}$ \\
\hline Unemployment & İşsizlik Oranı (\%) & $\begin{array}{l}\text { World Bank World Development } \\
\text { Indicators Veri Tabanı }\end{array}$ \\
\hline Gov_GDP & Devlet Harcaması (\% GSYH & $\begin{array}{l}\text { World Bank World Development } \\
\text { Indicators Veri Tabanı }\end{array}$ \\
\hline Fin_Open & Finansal Açıklık Endeksi & Chinn ve Ito (2006) \\
\hline Real_Trade_Open & Reel Ticari Açıklık Endeksi & $\begin{array}{l}\text { World Bank World Development } \\
\text { Indicators Veri Tabanı; Penn World } \\
\text { Tables 9.1; Yazarın Hesaplaması }\end{array}$ \\
\hline Fin_Dev*Econ_Glob & $\begin{array}{l}\text { Etkileşim Terimi } \\
\text { (Ağırlıkı Ortalaması Alınmış Finansal Sektör } \\
\text { Gelişme Endeksi* Ekonomik Küreselleşme } \\
\text { Endeksi) }\end{array}$ & $\begin{array}{l}\text { IMF Veri Tabanı; KOF Globalisa- } \\
\text { tion Index; Yazarın Hesaplaması }\end{array}$ \\
\hline$($ Fin_Dev*Econ_Glob)^2 & $\begin{array}{l}\text { Etkileşim Terimi Karesi } \\
\text { (Ağırlıklı Ortalaması Alınmış Finansal Sektör } \\
\text { Gelişme Endeksi* Ekonomik Küreselleşme } \\
\text { Endeksi) }\end{array}$ & $\begin{array}{l}\text { IMF Veri Tabanı; KOF Globalisa- } \\
\text { tion Index; Yazarın Hesaplaması }\end{array}$ \\
\hline Fin_Inst*Econ_Glob & $\begin{array}{l}\text { Etkileşim Terimi } \\
\text { (Finansal Kurumlar Gelişme Endeksi* Eko- } \\
\text { nomik Küreselleşme Endeksi) }\end{array}$ & $\begin{array}{l}\text { IMF Veri Tabanı; KOF Globalisa- } \\
\text { tion Index; Yazarın Hesaplaması }\end{array}$ \\
\hline$\left(\text { Fin_Inst }{ }^{*} E c o n \_G l o b\right)^{\wedge} 2$ & $\begin{array}{l}\text { Etkileşim Terimi Karesi } \\
\text { (Finansal Kurumlar Gelişme Endeksi* Eko- } \\
\text { nomik Küreselleşme Endeksi) }\end{array}$ & $\begin{array}{l}\text { IMF Veri Tabanı; KOF Globalisa- } \\
\text { tion Index; Yazarın Hesaplaması }\end{array}$ \\
\hline Fin_Mar*Econ_Glob & $\begin{array}{l}\text { Etkileşim Terimi } \\
\text { (Finansal Piyasalar Gelişme Endeksi* Ekono- } \\
\text { mik Küreselleşme Endeksi) }\end{array}$ & $\begin{array}{l}\text { IMF Veri Tabanı; KOF Globalisa- } \\
\text { tion Index; Yazarın Hesaplaması }\end{array}$ \\
\hline$($ Fin_Mar*Econ_Glob)^2 & $\begin{array}{l}\text { Etkileşim Terimi Karesi } \\
\text { (Finansal Piyasalar Gelişme Endeksi Ekono- } \\
\text { mik Küreselleşme Endeksi) }\end{array}$ & $\begin{array}{l}\text { IMF Veri Tabanı; KOF Globalisa- } \\
\text { tion Index; Yazarın Hesaplaması }\end{array}$ \\
\hline
\end{tabular}

\section{Kaynakça Bilgisi / Citation Information}

Özdemir, O. (2021). Finansal kuznet eğrisi ve ekonomik küreselleşme ilişkisi üzerine: OECD ülkeleri için gelir eşitsizliği temelli bir analiz. OPUS-Uluslararası Toplum Araştırmaları Dergisi, 17(38), 5271-5303. DOI: 10.26466/opus.748836 